\title{
An intelligent Scotland: Professor Sir Godfrey Thomson and the Scottish Mental Surveys of 1932 and 1947
}

\author{
Joint British Academy / British Psychological Society Lecture \\ read 17 October 2012 \\ IAN J. DEARY \\ Fellow of the Academy
}

Abstract: This article is a written version of the British Academy/British Psychological Society lecture given on 17 October 2012. In the first half the focus is historical on the work of Professor Sir Godfrey Thomson (1881-1955). In particular, new primary sources are described and illustrated. The principal new source is a collection of his public lectures from 1924 until 1954 that illustrate his interests and opinions in education and intelligence, and their place in society. The second half consists of an illustrative summary of our follow-up studies on the Scottish Mental Surveys of 1932 and 1947, in which Thomson played such a large part. These data are now being used in the study of cognitive ageing and cognitive epidemiology.

Key words: Godfrey Thomson, intelligence, education, ageing, mortality, morbidity.

I was grateful and honoured to be invited to present the joint British Academy/ British Psychological Society Lecture for 2012. I took the opportunity to describe the empirical building that we are erecting on the foundations provided by the Scottish Mental Surveys of 1932 and 1947, and also to describe the historical work we are doing to find out the origins that lie below the Scottish Mental Surveys. The lecture can briefly be described as a story about two buildings: one is a two-storey detached house in Ravelston Dykes in Edinburgh (Figure 1), and the clutter that I found in it (Figure 2); the other half of the lecture is a story about a University of Edinburgh building called Charteris Land and the clutter that we found in its basement (Figure 3). 


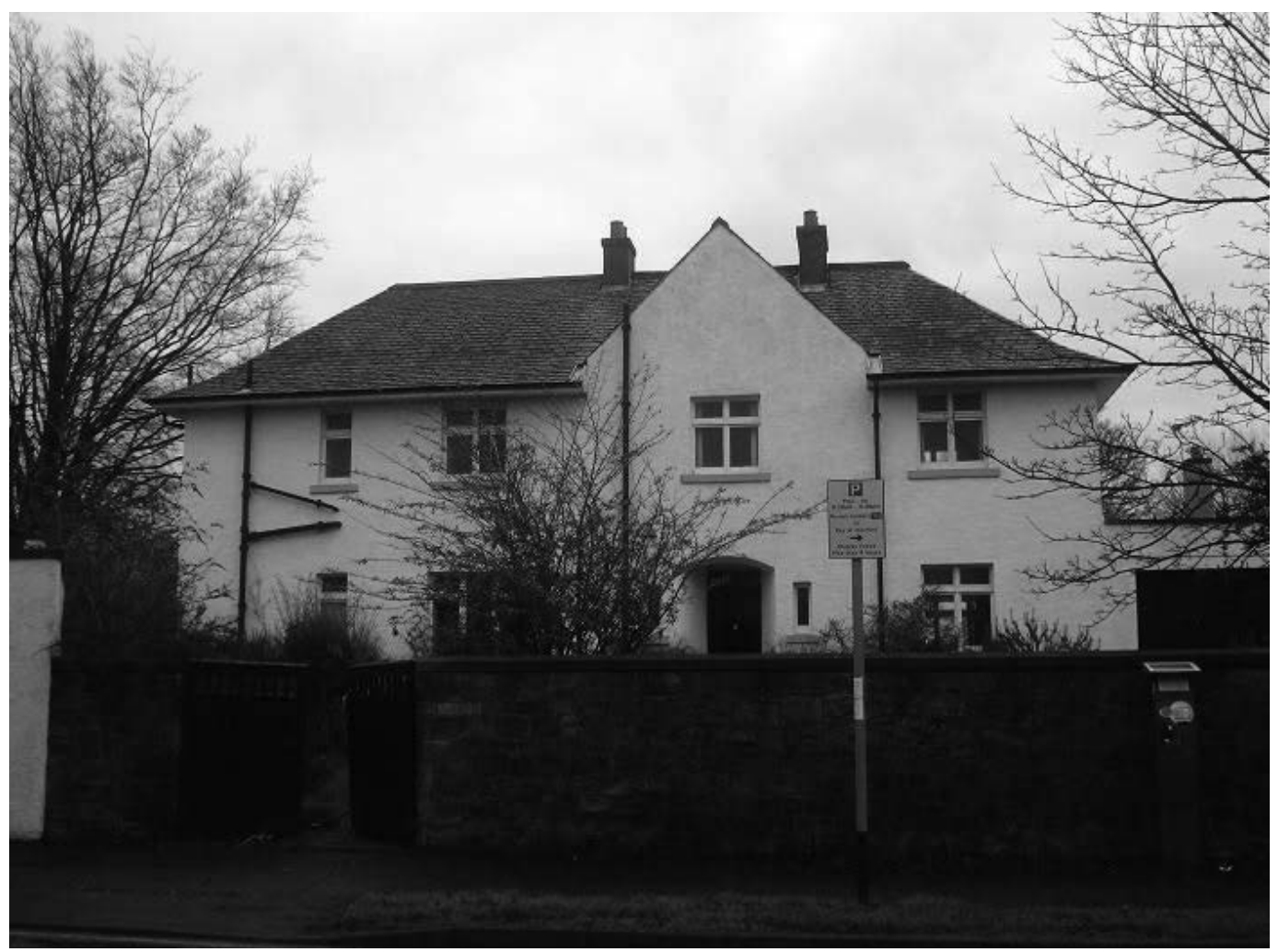

Figure 1. Godfrey Thomson's house at 5 Ravelston Dykes, Edinburgh. Photograph copyright Ian Deary. 


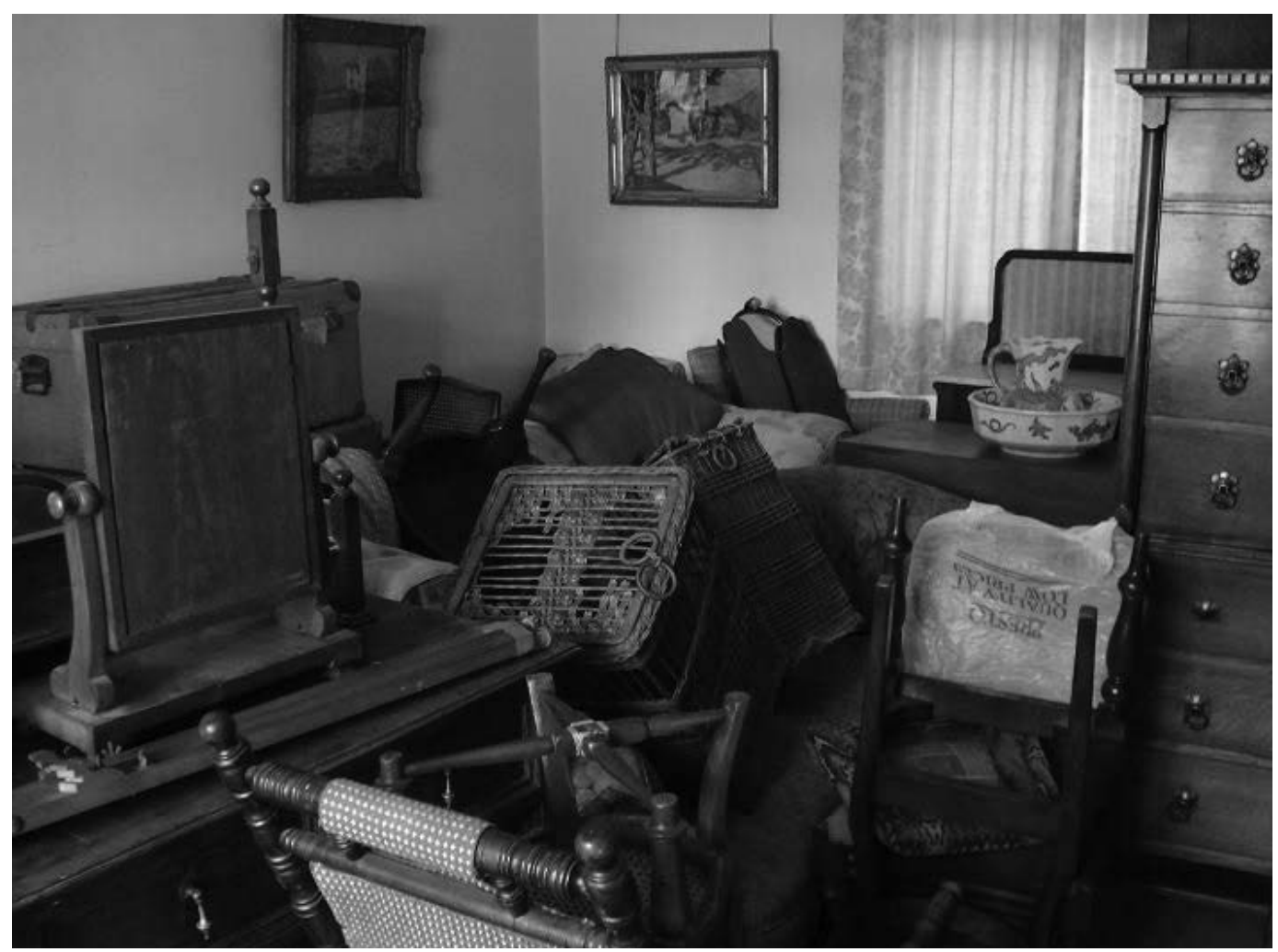

Figure 2. One of the ground floor rooms in 5 Ravelston Dykes at the time when I visited to retrieve the materials of what became the Hector Thomson Collection of Godfrey Thomson materials. Photograph copyright Ian Deary.

\section{PROFESSOR SIR GODFREY THOMSON}

First of all, here are some basics about Godfrey Thomson (1881-1955) (see Thomson 1952b; Sharp 1997; Figure 4). He was a 'lad o'pairts': a poor boy made good. Originally a pupil-teacher in Newcastle, he took a mathematics and physics degree. His Ph.D. in physics was in Strasbourg, then in Germany. By 1920 he was Professor of Education at Armstrong College, Newcastle. From 1925 to 1951 he was Bell Professor of Education at the University of Edinburgh. His work included education, statistics, and human intelligence differences. With regard to intelligence, he conducted a thirtyyear argument with Charles Spearman on the nature of human intelligence differences. This argument centred on Spearman's conceptualisation of general intelligence or $g$. Thomson also contributed to the statistical development of factor analysis. Factor analysis is a statistical method that is used to investigate whether a number of correlated variables can be reduced to a smaller number of latent traits. Thomson was 


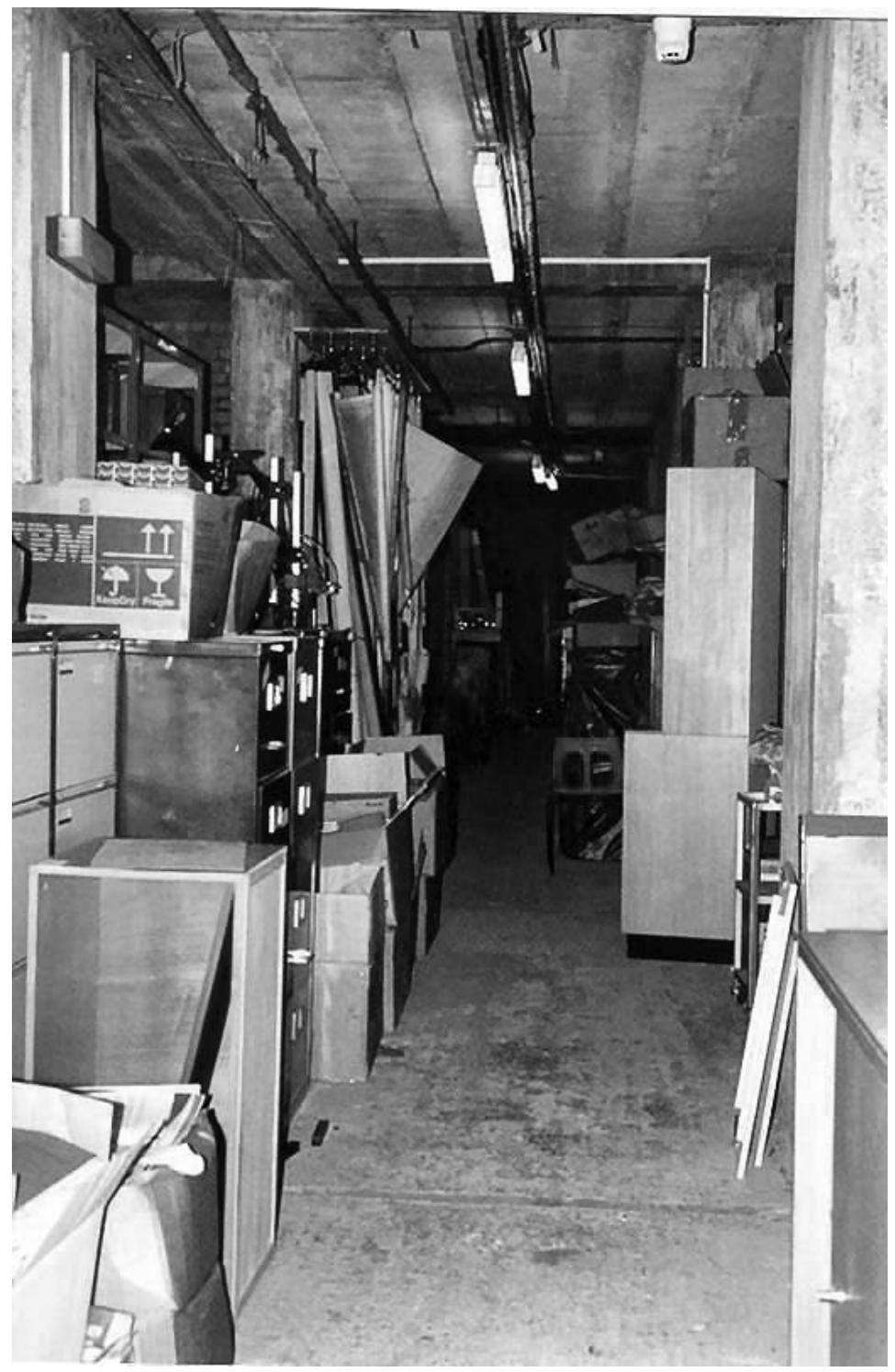

Figure 3. The basement of Charteris Land at Moray House College, University of Edinburgh in 1997. At the end of this corridor was the locked area where the Scottish Council for Research in Education had stored the data from the Scottish Mental Surveys of 1932 and 1947. Photograph copyright Ian Deary.

heavily involved in selection from primary to secondary school during the second quarter of the 20th century. Although he was somewhat ideologically opposed to selection based on intelligence tests, he contributed a great deal to this. His Moray House Tests, which he developed and validated and distributed, were used to test school pupils in a large number of education authorities in England. It is recorded 


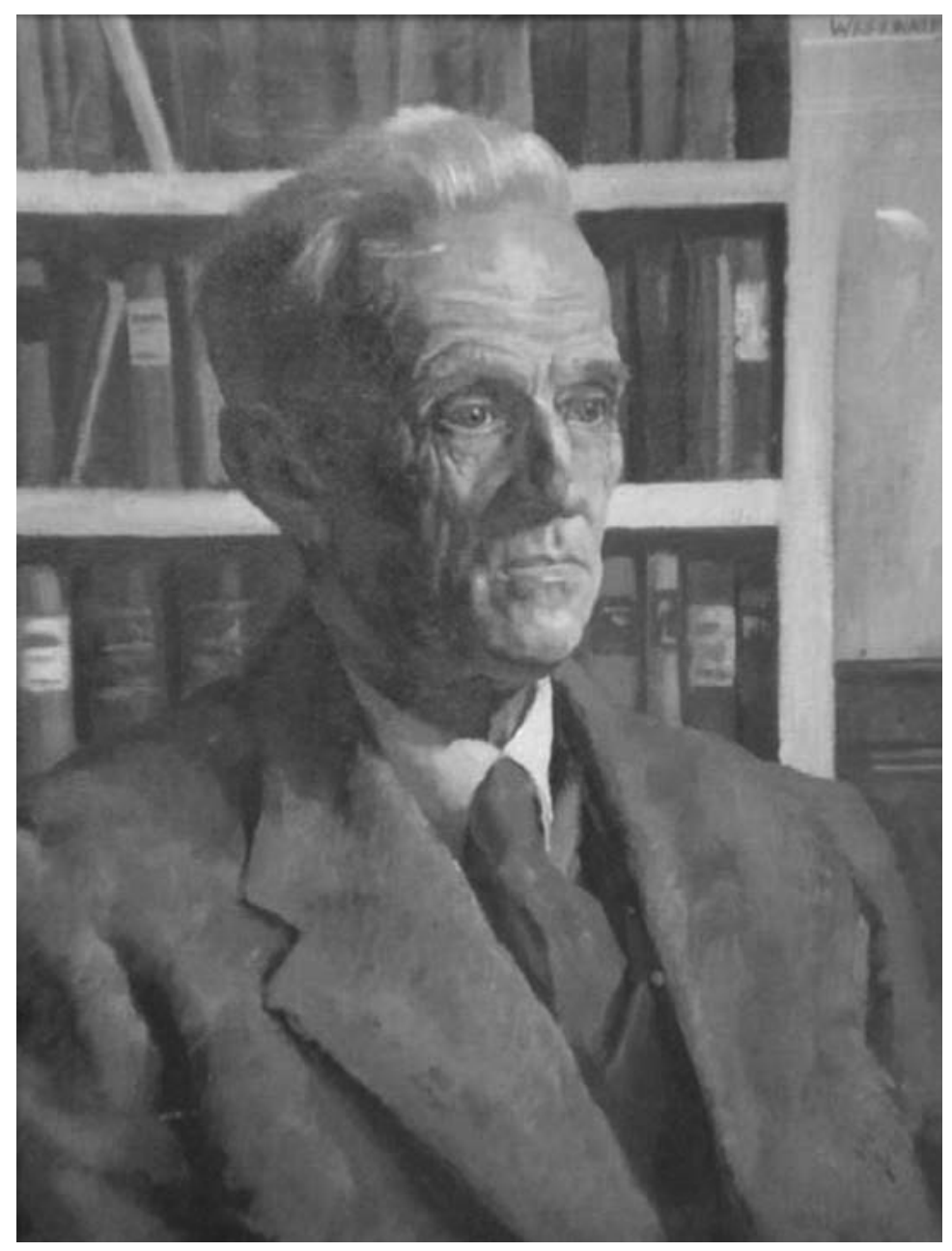

Figure 4. Professor Sir Godfrey Thomson, painted by Robert Heriot Westwater in 1950. Photograph copyright Ian Deary.

that, in one year, his one-room research group in Moray House Teacher Training College in Edinburgh distributed more than one million tests (Vernon 1962). Thomson was the statistical chairman for the Scottish Mental Survey of 1932 and the Chairman of the Scottish Mental Survey 1947 (Deary et al. 2009a).

Given that his work in education, statistics, and intelligence was all substantial and made him world-famous in the first half of the 20th century, it is striking that he is barely remembered in any of these fields today. That was why, using an ESRC grant, I collaborated with Professors Martin Lawn and David Bartholomew (with expertise in educational history and statistics, respectively) to conduct work on Thomson's history. One of the problems we found was that there was so little information on him: 
there was no archive. One of the few sets of documents that were available was the ledgers of the Moray House Tests placed in the Special Collections section of the Main Library at the University of Edinburgh. As we researched, we came across additional information (documented in Deary et al. 2010b): the correspondence between Thomson and his mathematical assistant Walter Ledermann; some correspondence with the statistician Maurice Bartlett; the annual reports of Thomson's 'Room 70' research group; some of Thomson's personal papers; one of Thomson's day books; a few annotated books with notes in Thomson's hand; Thomson's reprint collection, with a few annotated papers; the transcripts of the International Examinations Inquiry; notes made by Thomson's successor in research-Albert Pilliner; and sundry other materials.

Outside the University of Edinburgh, we found correspondence with the statistician R.A. Fisher, and Thomson was also mentioned in papers of the Eugenics Society, the Cyril Burt and Charles Spearman archives, the Carnegie Archives on the International Examinations Inquiry at Teachers College Columbia, the Scottish Council for Research and Education Mental Survey archives, and the Population Investigation Committee archives.

We conducted interviews with some of Thomson's surviving acquaintances. For example, I interviewed Walter Ledermann (Thomson's mathematical assistant in the late 1930s), Elsie Taylor (statistical clerk in the Room 70 team), Marion Cooke (Thomson's secretary), Vida MacFarland (wife of one of Thomson's research assistants), Catherine Hunter (a trainee teacher at Moray House), Sheila Anderson (daughter of Pilliner), Cecily and Margaret Giles (family friends), John Nisbet (one of Thomson's B.Ed. students and one of the testers in Scottish Mental Survey 1947), Ian Morris (of the Scottish Education Department), and David Finney (who met Thomson as a young academic) (Deary et al. 2010b).

Until now we have used the above-mentioned interviews occasionally for examples in some of our research papers on Thomson's work (e.g. Lawn et al. 2009). However, we have not, yet, used the interviews as an historical source in their own right and pulled together the themes emerging from them. What does emerge from them, when they are taken together, is: that Thomson was clearly considered to be outstanding in his profession; that his modest roots and success story were pretty well known; and that he correspondingly had a mission to make it possible for those from poor backgrounds to make it to the top where possible. With regard to his major responsibilities - at the Moray House Teacher Training College, for the Room 70 research team who produced the Moray House Tests, at the Scottish Council for Education who conducted the Scottish Mental Surveys, and in his supervision of theses for the B.Ed. degrees which were highly prestigious - he was known as a delegator. That is, he had the ideas in each of these areas but was happy to let people get on with them. He was especially heavily involved in the later of the two Scottish Mental Surveys. Those who saw him in teach- 
ing saw him as an 'actor': he was absorbed in what he was teaching, presented material that was very challenging, was sometimes described as ruthless with regard to those who could not cope with fairly mathematical materials, and promoted those whom he saw as able, especially in the setting of the elite Edinburgh B.Ed. degree and its theses. He was often characterised as fair and generous with examples being given of the latter. He was thought to be competitive in his academic field. He was seen as somebody who encouraged younger academics to whom he would act as a father figure. He was described as organised, stimulating, joyous, courteous, having high standards, and being humorous, warm, talkative, sociable, charismatic, lively, and of high integrity and power. However, some of this is clearly specific to the individuals being interviewed, because he was also described as having not many friends, not being approachable, and being somewhat distant. Even his voice attracted some contrary opinions. Cecily and Margaret Giles described his voice as lovely, especially because of his northeast of England burr. On the other hand, Ian Morris described his voice as squeaky. It was occasionally mentioned that Thomson tended to stop and play the piano at the Moray House Teacher Training College for the benefit of the students.

There is insufficient room here to provide examples of many of the interviews but, for example, Walter Ledermann, who worked with Thomson in the late 1930s during the time that Thomson was preparing his famous book on factor analysis of intelligence, describes Thomson's work in the following way: 'It was very regular, the meetings were very business-like but he was extremely well organised, he always had it exactly planned what to do over the next day or two. He was never pedantic, never bullying people but it was just taken for granted that the research was done in a very systematic way from day to day like a planned piece of research' (Ledermann 2006). One of the privileges of the research was that Thomson's statistical clerk Elsie Taylor had drawn out for us a map of where people sat in Room 70, producing the then famous Moray House Tests. Prior to that, we had not known the organisation of the personnel. Elsie Taylor recalled something of the ethos of the B.Ed. classes in which Thomson taught: 'The one characteristic that I do remember, he was clearly in dispute with Professor Cyril Burt, whose line and contribution at that stage as I understand was called simple summation whereas Professor Thomson was challenging this with factorial analysis [Taylor is referring to two different approaches to reducing a list of correlated variables to a smaller number of latent traits] and occasionally one of them would murmur "simple summation" and that would light him up!' (Taylor 2007). In another interview, John Nisbet (2006) recalled Thomson's lending fees for the Edinburgh B.Ed. degree to his brother Stanley so that he could complete it. They had also come from a poor, one parent family.

Sheila Anderson, the daughter of Thomson's research successor Albert Pilliner, recalled that one of the reasons that the Moray House Testing 'industry' declined after Thomson left was that Thomson's successors to the Chair of Education in 
Edinburgh were clearly different in research preferences from Thomson. His immediate successor was Professor John Pilley and, as Sheila Anderson (2007) said,

Professor Pilley ... was completely different from Professor Thomson. He was a strange man - I do remember him - the families were quite close. He had a wonderful wife I was very fond of and two boys sort of about my age. He was probably I think a terrific snob, you know, he was a sort of Brideshead type from the thirties. He, according to Elsie Taylor, you will have to talk to her yourself, when he came in he surveyed the Department with distaste and said, 'I didn't realise I'd inherited a pharmaceuticals department'. Yes, I should suppose it was all these chemists.

Thomson had hired two statisticians for his Room 70 who had previously been in the chemical industry. The person who followed Pilley was Liam Hudson, who also had limited time for mental tests. It is interesting that, compared to the poor-boy Thomson, Pilley and Hudson had gone to prestigious private schools (Dulwich College and the Whitgift School, respectively) and then on to Oxford.

Among other things we discovered of Thomson's that were previously unknown were several artefacts: some photographs, more reprint boxes, Thomson's stopwatch, and his calculating machine. One of the most useful artefacts we discovered was from Vida McFarland, and was a recording of Thomson lecturing in 1950 to University of Edinburgh staff on how to lecture. We have published a separate article on this (Lawn et al. 2009) and it is revealing about Thomson's clear and humorous lecturing style. It also resolved the varied opinions about Thomson's voice; it wasn't squeaky during the lecture. Its main benefit, though, was to document Thomson's contribution to university-level teaching.

In summary, our historical research on Thomson to date has resulted in eight articles specifically on Thomson. Some of these were on Thomson's contribution to statistics, to factor scores, and his statistical theory of human intelligence differences (Bartholomew 2009a,b,c, respectively). In these three articles we demonstrated the little-appreciated contributions that Thomson made to multivariate statistical analyses of cognitive data. Others covered Thomson's contributions to psychology and intelligence, including transcribed conversations between him and Charles Spearman and Edward Thorndike (Deary et al. 2008a), and his Ludwig Mond lecture (Deary et al. 2009b). In these two pieces we demonstrated Thomson's advanced thinking about the nature of intelligence, and how he saw intelligence as relevant to wider concerns about civilisation and citizenship. We also describe in more detail the archival sources we have identified on Thomson, that are available for other scholars (Deary et al. 2010b). We also covered Thomson's contribution to educational research (Lawn et al. 2010) and to university pedagogy (Lawn et al. 2009).

To emphasise just one of these contributions, our re-examination of Thomson's ideas made it plain that Thomson's bonds theory of intelligence - which was a counter 
to Spearman's $g$ theory-could stand both statistically and biologically against Spearman's currently popular theory of intelligence today (Bartholomew et al. 2009a). Thomson and Spearman disagreed about why mental tests all tended to correlate positively. Spearman's idea was that there was a capacity called general intelligence (which he abbreviated to $g$ ), and that all mental tests called upon this capacity to some extent, as well as calling upon specific cognitive abilities. This meant that it was important to try to discover the nature of this $g$. At the time, Spearman suggested it might be a general mental energy. On the other hand, Thomson thought that mental tests correlated because they drew upon overlapping sets of 'bonds' in the brain. His idea was that the brain was made up of a large number of 'bonds' - by contrast with Spearman's unitary $g$ - and that each cognitive test drew upon a subset of these for its successful completion. This meant that it was important to discover the nature of these bonds. At the time, Thomson used phrases like neural arcs. Neither modern statistical methods nor modern neuroscience can choose between these accounts: Spearman's monarchic theory of intelligence, and Thomson's anarchic theory. We demonstrated this by presenting the first formal mathematical account of Thomson's bonds theory of intelligence, and by assessing it and Spearman's ideas against recent research on brain structure and function and their associations with cognitive abilities.

\section{THE HECTOR THOMSON COLLECTION AND GODFREY THOMSON'S LECTURES}

When we were well on the way to completing these historical searches and papers, a new Godfrey Thomson collection came to light. I was called by Godfrey Thomson's great-niece-Annabella Senior - on 8 July 2008 to say that, following first the death of Thomson's son and then his daughter in law, the house in Ravelston Dykes in Edinburgh, in which Thomson and his son had both stayed since 1926, was being emptied, and that there might be some material of interest. These included many of Thomson's books, personal effects, photographs and artefacts. There were many letters, heavily annotated revision notes for editions of Thomson's own books, some unpublished books, and a pile of Thomson's lectures. Some of the lectures were in Thomson's hand and some were typed (Figures 5 and 6). Thomson had often underlined the contents, and had sometimes written the number of words and the time it would take him to deliver the lectures. The lectures ranged in date from 1924 to 1954, covering the year before he arrived in Edinburgh until a few years after his retirement. They were given to a number of organisations, from schools, through lay and business people, to student groups and academics. They cover most of Thomson's interests and are a large, valuable and 


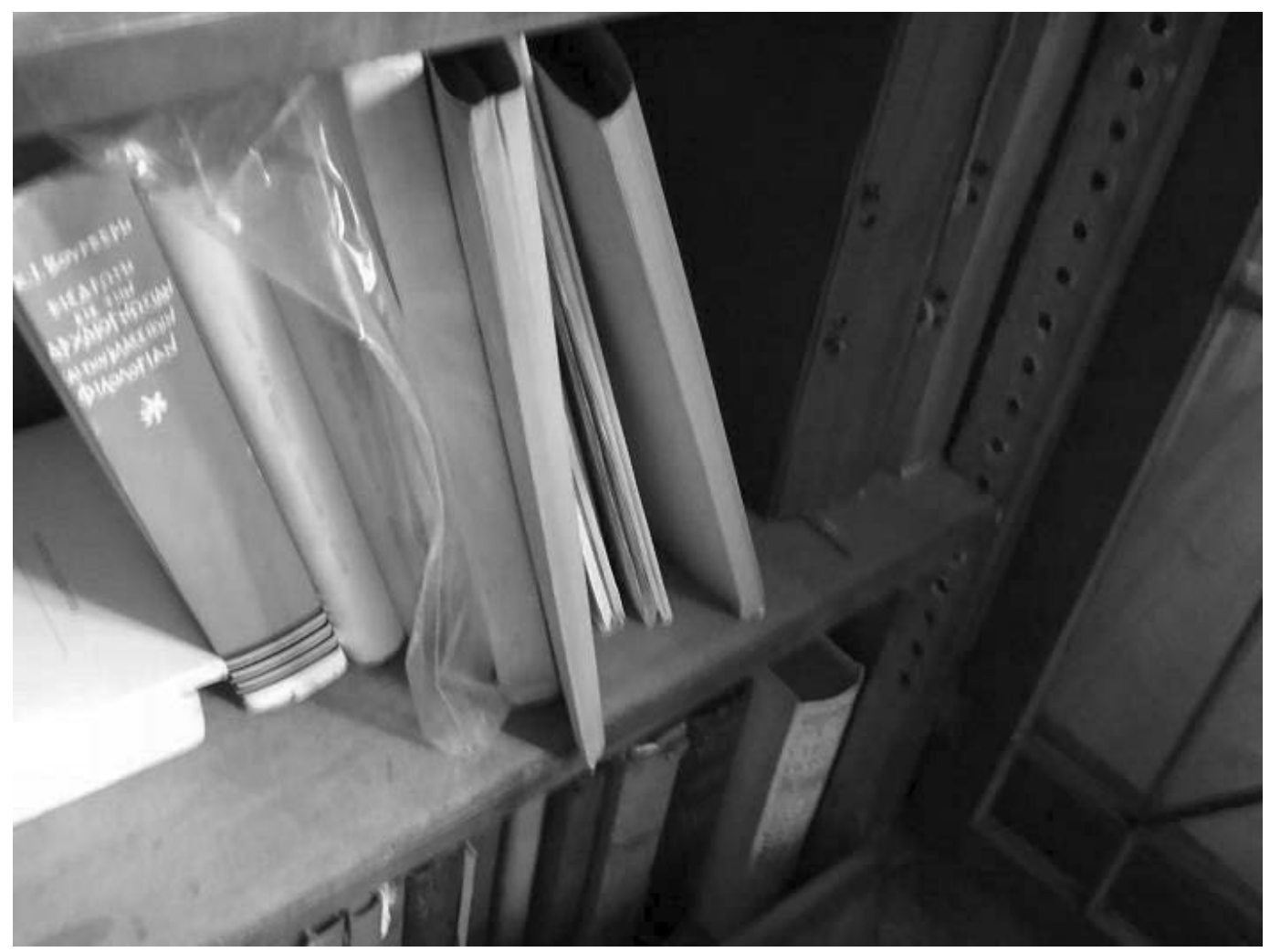

Figure 5. The dark folder to the right of the photograph contains Godfrey Thomson's lectures. This was their situation at 5 Ravelston Dykes. Photograph copyright Ian Deary.

hitherto unknown source of information for Thomson and his opinions.

A number of themes emerged from the lectures, on which we have not previously written. A summary of the themes will be given here, and some example quotations will follow. Probably most prominent was Thomson's professional mission to find and properly educate children from poor backgrounds. He called education the 'food of the Gods' (Thomson 1925). He thought, unusually for the time, and consistently from the 1920s until the end of his career, that education should be comprehensive (everybody should go to the same kind of school), that it should continue for all until at least age 16 years, that it should be flexible insofar as people should be able to move between academic and practical tracks, that each person's education should cost the same amount, and that there should be variety in addition to the standard academic type of education. Although he contributed to it, he thought that selection for education by just a single test was inappropriate. Rather, he thought that a 'time exposure'-a phrase that he uses in different lectures — was necessary such that a person's 


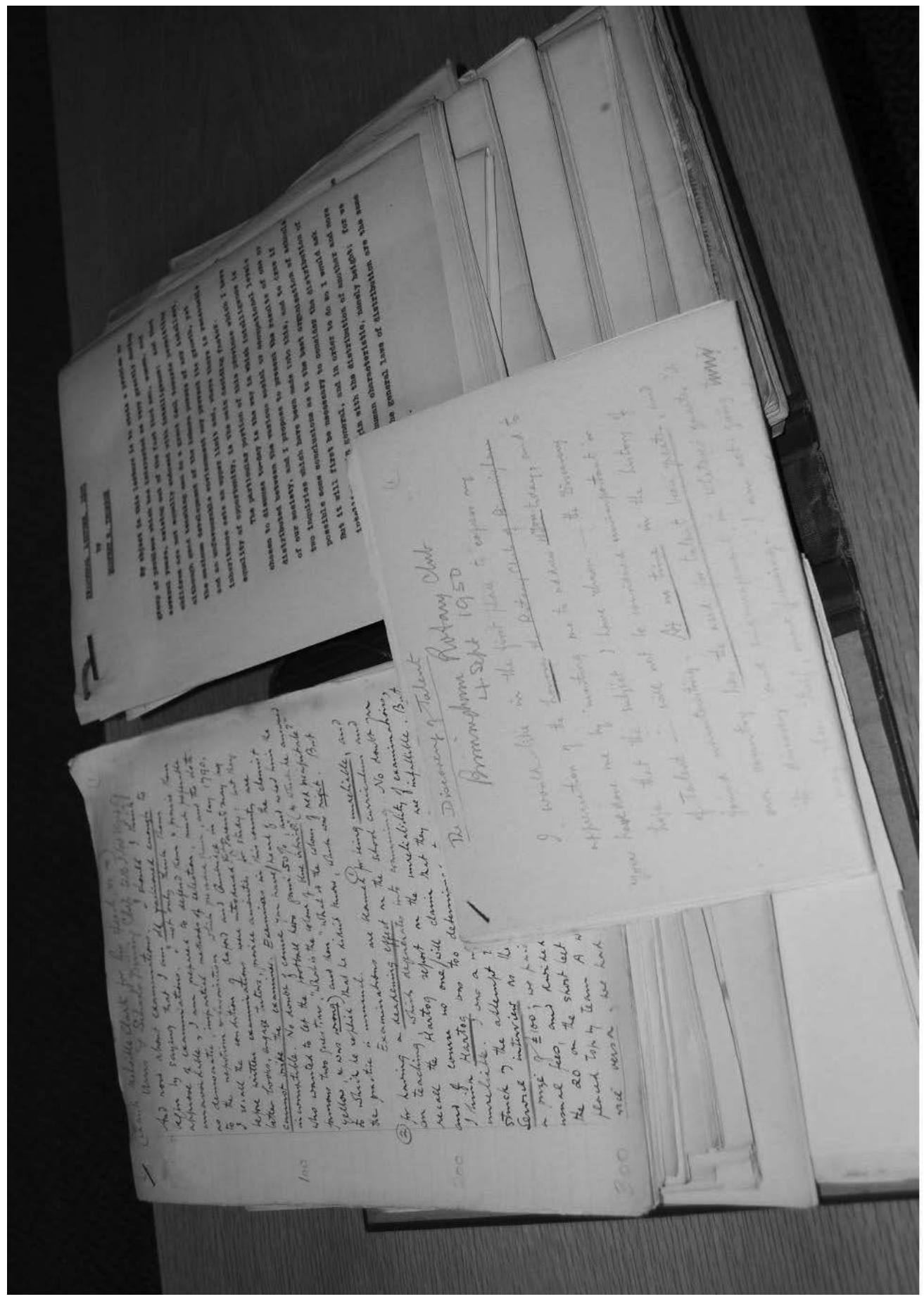

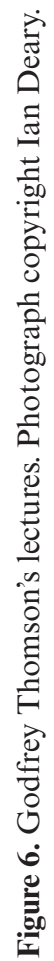


ability and attitude could be gathered fairly. This was unusual for the time, when selection for educational streams tended to be based on assessment at the end of primary school (about age 11) and not repeated. He thought that examinations, though far from perfect, were fair, and protected society against promoting those who were merely well off or socially well-positioned. He talked a great deal about his thoroughness in designing intelligence tests, about social origins and social mobility, and about the differential birth rate whereby the poorer classes were having more children whereas the middle and professional classes tended to delay their childbearing or not have children at all. There was much social concern at the time in Britain that the nation's intelligence would decline through the lack of breeding among brighter individuals: the so-called differential birth rate. There was some discussion by Thomson of educational and psychological research as organised by the Scottish Council for Research and Education. There was mention of the Scottish Mental Surveys of 1932 and 1947. Indeed, the latter is noted especially because it was used to test the differential birth rate hypothesis. There was also mention of education's being or having an aim to increase people's happiness. The lectures also contained several jokes, showing that Thomson did leaven his lectures with humour. I now offer a small selection of quotations - in chronological order from the lectures - to illustrate some of these themes.

In short, I would urge a time-exposure rather than a snapshot examination for this important sifting of children into their post primary classes. (Thomson about 1929)

Nothing can shake my belief that every child ought to have an equal chance of any kind of education in open competition with other children, uninfluenced by the wealth or position of its parents and as far as we can manage it uninfluenced by the topographical position of its home. (Thomson 1930a)

It is certainly true that there is a differential birth rate at present, and that the more capable classes of the community marry later and have smaller families than the less capable, and this problem is in my opinion the most important social problem we have with us today. (Thomson 1930a)

We must give the best education they are capable of enjoying to everyone, even if the consequence should be, that the highest intelligence should be slowly bred out of the race. (Thomson 1930b)

That latter quotation shows that, although Thomson was worried about the differential birth rate, he thought that the duty to educate everyone to their ability outweighed the possible societal consequences of doing so.

The essential thing which I require is that the same amount should be spent on each individual during his lifetime, disregarding entirely both his needs and his abilities. The same total amount in every case. I do not wish to spend a halfpenny less on the 


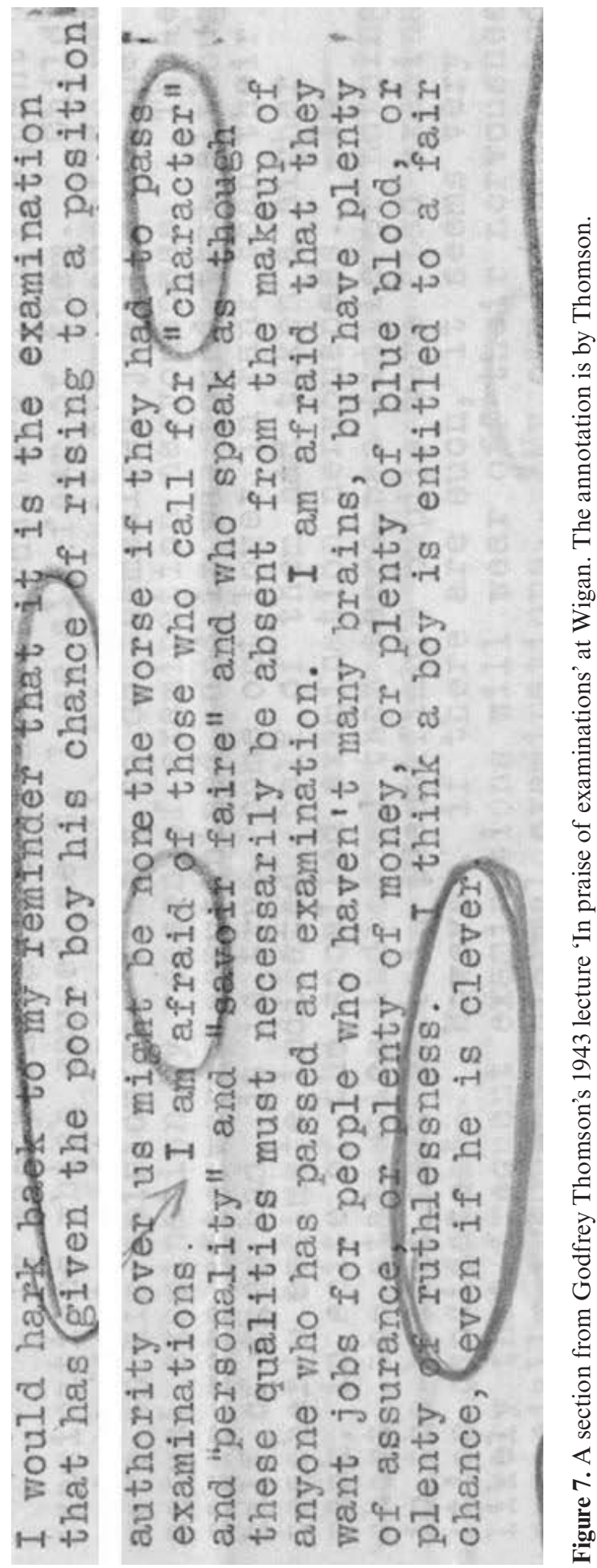


highly intelligent. (Thomson, 1942)

I am afraid of those who call for 'character' and 'personality' and 'savoir faire' and who speak as though these qualities must necessarily be absent from the makeup of anyone who has passed an examination. I am afraid that they want jobs for people who haven't many brains but have plenty of assurance, or plenty of money, or plenty of blue blood, or plenty of ruthlessness. I think a boy is entitled to a fair chance, even if he is clever. (Thomson, 1943; Figure 7)

Even late in Thomson's career-into the 1950s - he was going over again the reason why he first developed mental tests, which he did in Northumberland before those in Edinburgh under the Moray House Test banner. For example, in 1950 he describes how one boy who was tested in Northumberland in 1921 wrote to him as follows, "II have often wished to write to you but have never found the courage till now, when I have just won the gold medal at the end of my medical course, and I thought you would like to know." I did like to know and felt warmed at heart' (Thomson 1950).

In modern terms, these lectures would be seen as Thomson's knowledge exchange; he was taking his academic interests - the theories, results and practical applications - and discussing and applying them far beyond the university setting. They make clear his motivations and his principles together with his empirical work. Fuller descriptions and analyses of Thomson's lectures and other materials from the Hector Thomson collection are planned as separate articles. Here, the short account of the lectures has been used to shed some light on a once-prominent academic and public figure who is now mostly forgotten or misunderstood.

In one of Thomson's later lectures he went over the results of the Scottish Mental Survey of 1947 (Thomson, 1952a). In it, he especially mentioned the 1,200 children of a small subsample whom they had intended to follow up for the rest of their lives, investigating the effect of their background and intelligence on their ultimate education and occupations. Research that I have been involved in since the late 1990s has followed up some of Thomson's data; some of that research was along the lines Thomson foresaw, and some of it has taken directions he could not have predicted.

\section{THE SCOTTISH MENTAL SURVEYS OF 1932 AND 1947}

In 1931 Thomson, along with other luminaries in education and intelligence from Scotland, Switzerland, England, France, Germany, and the United States of America, gathered at the International Conference on Examinations under the auspices of the Carnegie Corporation, the Carnegie Foundation, and the International Institute of Teachers College Columbia University (Deary et al. 2008a). Their interest was in how to validate examinations for assessment and selection in schools, and international 
concerns about these processes. One of the outcomes of the conference was that each country should conduct a research exercise and report back. In Scotland it was decided that the task was to test the entire nation's intelligence. This was done in the Scottish Mental Survey of 1932 (Scottish Council for Research in Education 1933). The test used was Godfrey Thomson's Moray House number 12, a test of 'verbal reasoning' which had many verbal reasoning items, but also some numerical, spatial and other types of reasoning. This was a general IQ-type test that was used at age 11 years for selection into secondary schools, mostly in England. So, on Monday, 1 June 1932, Scotland tested 87,498 children - about $95 \%$ of the 1921-born population at school in Scotland in 1932.

The exercise was repeated on Wednesday, 4 June 1947. The same Moray House test was applied to those born in 1936 (Scottish Council for Research in Education, 1949). The rationale was rather different, this time not being based on an educational question. Indeed, the stimulus came from the UK's Population Investigation Committee, which wished to investigate the differential birth rate; that is, the concern that the more professional occupational classes were delaying having children, and generally having fewer children than the more manual classes. This had interested Thomson from early in his career. He had reported a correlation between intelligence and social class in his research in Northumberland (Duff \& Thomson 1923), and had found negative correlations between intelligence and family size. Here is a brief summary of the rationale from the Scottish Council for Research and Education (1949):

At the annual meeting [of the Scottish Council for Research in Education] in June 1945 Professor Godfrey Thomson brought to the attention of the Research Council a suggestion made by Dr J.A. Fraser Roberts and conveyed to Professor Thomson by Sir Alexander Carr-Saunders, Chairman of the Population Investigation Committee, that in view of the presumed decline of national intelligence by reason of a differential birth-rate the Research Council should undertake a repetition of the 1932 Mental Survey, applying the same test to the corresponding age group, to secure evidence as to whether there had been any change since the original application.

In the existing correspondence in the Population Investigation Committee records and the Eugenics Society records (in the Wellcome Trust in London), there are letters between Carr-Saunders and Thomson, and also to and from the sociologist David Glass. Some of this correspondence was to try to persuade Thomson that it was better to retest the entire population rather than a sample. The funding for the Scottish Mental Survey 1947 also came from the Nuffield Foundation and the Eugenics Society (see chapter 1 of Deary et al. 2009a for a summary of the Surveys' history).

The Scottish Mental Survey 1947 found that the empirical data showed the opposite trend to that predicted by the differential birth rate. That is, the children born in 1936 (tested in 1947) scored a few points higher on the same test than did the children 
born in 1921 (tested in 1932). However, Thomson, in his lectures, continued to consider the possibility that other factors might have affected this result, and that a dysgenic trend in intelligence test scores could not firmly be excluded by the results (also see Ramsden 2007). For example, Thomson was concerned about whether the contents of mental tests were becoming more widely known amongst the public and that the test score increase might be an artefact of this. Thus, he was still writing to Blacker of the Eugenics Society in 1949 that a 'Galton Subsidy' might be a good idea: that is, it might be worth seeking poor families that had bright children so that they could be

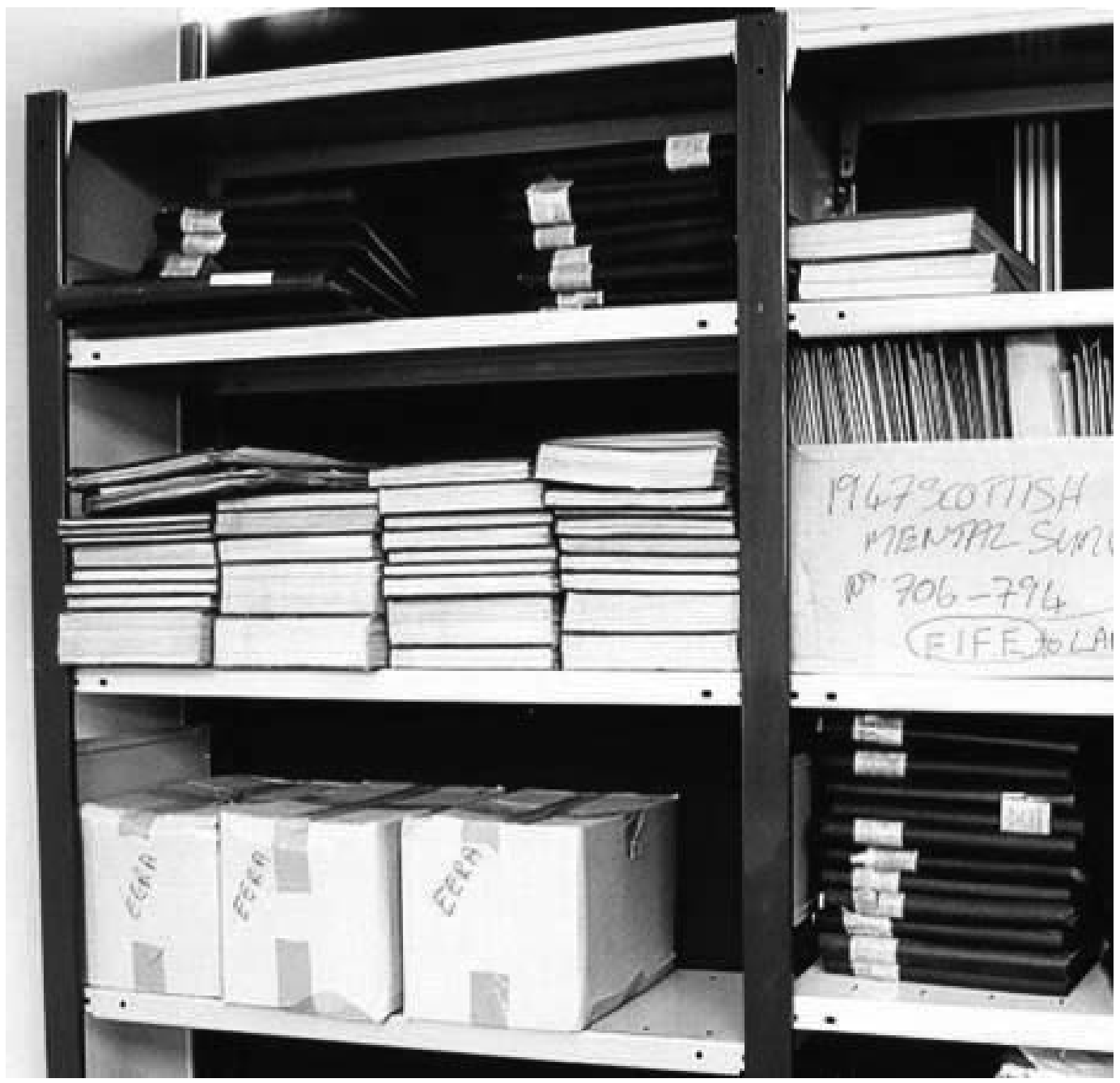

Figure 8. The ledgers that contain the original data from the Scottish Mental Surveys of 1932 and 1947. The 1932 Survey's ledgers are those to the left of the middle shelf. The 1947 Survey's ledgers are those on the left of the top shelf and the right of the bottom shelf. Photograph copyright Ian Deary. 
given extra funds to undertake educational courses.

\section{FOLLOW-UP STUDIES OF THE SCOTTISH MENTAL SURVEYS}

At this point I turn from the historical work to our empirical research. Clearly, in our historical research there is a great deal of work to be done with the Hector Thomson Collection and we look forward to analysing these primary sources in the next few years. The topic for the rest of this article is a summary of our follow-up studies Scottish Mental Surveys of 1932 and 1947.

It was clear to me and my initial co-principal investigators, Professor Lawrence Whalley and Professor John Starr, that the Scottish Mental Surveys provided an unusual opportunity to those of us interested in human life-course studies. Lawrence Whalley and I came across the surveys in the late 1990s, as we have described elsewhere (Deary et al. 2009a; Figure 8). First, the Scottish Mental Surveys provided a baseline measure of cognitive function against which cognitive function might be compared when people had arrived in old age. It was therefore a rare opportunity to study life-course cognitive ageing. Turning things the other way round - and thinking of cognition as the predictor and not the outcome of research studies - the Scottish Mental Surveys also provided a rare opportunity to find out what the consequences were of different levels of cognition in childhood for health later in life. That is, they provided an unusual opportunity to study 'cognitive epidemiology': the association between cognitive ability in youth and health, illness and death in later life.

In Scotland, cognitive ageing follow-up studies have been conducted for those who took the Scottish Mental Survey tests and are now living in Aberdeen and Edinburgh. Because of space limitations, I describe the studies that I have led in Edinburgh: those of the Lothian Birth Cohorts of 1921 and 1936 (Deary et al. 2012a). The Lothian Birth Cohort of 1921 (LBC1921) was originally 550 strong. Most had taken the Scottish Mental Survey's Moray House Test No. 12 at age 11 in 1932. My team originally saw these individuals between 1999 and 2001 at age 79, again at age 83, and age 87, and at 90 (in 2011). The Lothian Birth Cohort 1936 (LBC1936) originally numbered 1,091 individuals. They had taken part in the Scottish Mental Survey 1947. My team first saw them at age 70 between 2004 and 2007; they were seen again at age 73, and they are being seen at age 76 during 2012 and 2013. Our work in tracing, recruiting, testing and following up these individuals is described in several articles (Deary et al. 2004, 2007, 2012a).

When calling back these individuals for further testing we conduct a long series of cognitive tests (including retesting on the original age 11 test again in old age). In the LBC1936 there are 16 cognitive tests. These tests include assessments of memory, 
processing speed, executive function, vocabulary, and spatial ability. They also undergo a detailed magnetic resonance imaging structural brain scan (Wardlaw et al. 2011). A genome-wide scan is undertaken on each person for over 600,000 genetic tests of single nucleotide polymorphisms. In addition, there are also tests for sensory function, physical fitness, anthropometry, retinal vessel photography, blood is taken for many bio-markers, and a large questionnaire is used to investigate diet, personality, satisfaction with life and other psychosocial measures. In addition to these tests, a medical examination is undertaken.

\section{RESULTS FROM FOLLOWING UP THE SCOTTISH MENTAL SURVEYS OF 1932 AND 1947}

In what remains of this article, I describe some of our work with the follow-up studies of the Scottish Mental Surveys. In doing so, I refer to some of the quotations from Godfrey Thomson's lectures that we discovered in his house in Edinburgh. They provide a nice set of heralds for what we did. And, I begin with the following: 'Perhaps some of you may serve on a mental survey committee of the future when we, if we are still living, are too old' (Thomson 1948). Indeed we have done that. The first ten years of our research on the Scottish Mental Surveys of 1932 and 1947 were published in the book A Lifetime of Intelligence (Deary et al. 2009a). The Lothian Birth Cohorts alone have resulted in over a hundred peer-reviewed articles and it is impossible to give an account of more than a small minority of them. I have attempted a fuller summary elsewhere (Deary et al. 2012a). Here, I attempt to give an overview of the types of research we have and are conducting, to give an overview of the findings, and give illustrations of some individual findings. I also explain why these specific answers to research questions could not have been provided without the childhood cognitive data from the Scottish Mental Surveys of 1932 and 1947.

\section{The stability of intelligence from childhood to old age, and how childhood intelligence predicts survival to old age}

These two topics are the foundations of our research on cognitive ageing and cognitive epidemiology, respectively.

On cognitive ageing, the follow-up studies of the Scottish Mental Surveys afforded us the opportunity to study the stability of individual differences in intelligence over a far longer period of the human life course than had been attempted previously. This is important for at least two reasons. First, intelligence is an important human trait, and it was not known how stable people's differences were from 
childhood to older age. Second, the ageing of society means that the determinants of successful cognitive ageing are being sought. To do that, one needs information about the cognitive levels at which people started in youth, and then to test the same people later in life. The Scottish Mental Surveys allowed this type of life course approach.

An early paper from the studies reported the stability of individual differences in intelligence - using the same, Godfrey Thomson-devised Moray House Test - from age 11 up to the mid-70s (Deary et al. 2000). The correlation was between 0.6 and 0.7, showing that there is moderately high stability in intelligence differences between childhood and old-age. In further papers we replicated this, showing a correlation between age 11 and around 80 of 0.66 (Deary et al. 2004; Gow et al. 2011). These results show that there are factors which retain people's rank order of intelligence throughout most of the human life course. On the other hand the results also show that there is substantial change in people's rank order of intelligence from childhood to old age. That change interested us particularly, because we wanted to discover the determinants of the changes, which told us that some people were doing better, cognitively, than expected in old age, and others were doing less well.

The degree of stability of and change in intelligence differences between childhood and old age provided a foundation. It gave an estimate of how much of cognitive variation in old age could be accounted for by life-long trait stability, and how much was caused by factors across the life course that resulted in change from the childhood baseline. Much of our subsequent research has sought these determinants of change, including genetic and environmental factors (Deary et al. 2009a, 2012a give overviews of this research).

Another early report from our follow-up studies of the Scottish Mental Surveys' data is one which allowed us to begin the study of the area we named cognitive epidemiology. Using data from people who had taken the Scottish Mental Survey test of 1932 in the Aberdeen area, we found that there was a significant association between IQ at age 11 and survival up to age 76 (Whalley \& Deary 2001). Indeed, we found that, on average, a girl who had a 30-point advantage on IQ at age 11 over another girl was about twice as likely to survive to age 76 . In subsequent research, including the largest meta-analysis, undertaken by one of our Centre's Ph.D. students, these results have been replicated (Calvin et al. 2011). On average, it is found across all studies which have examined this question that there is an association between higher intelligence and living longer; that is, a one standard deviation (15 IQ points) advantage in intelligence in childhood is associated with about a $25 \%$ lower risk of dying in middle to old age.

As was described above with cognitive ageing research, this association between childhood intelligence and mortality provides the foundation for further research. It 
was important to find out the cause of such an association, and to answer questions such as: 'Is the association independent of social class and education?'; 'Does the association hold for all causes of death?'; 'Is the association caused by different types of health behaviours?' There is an overview of this research in Deary et al. (2010a).

I now turn to some examples and overviews of cognitive ageing and cognitive epidemiology research that has been undertaken using the data from the Scottish Mental Surveys.

\section{Determinants of cognitive ageing}

By tracing, recruiting, and retesting in later life people who had taken part in the Scottish Mental Surveys at age 11, we have been able to test hypotheses about which factors are associated with people's differences in cognitive ageing. We have examined a wide range of factors: genetic, psychosocial and lifestyle, and biomedical. An overview is given in Deary et al. (2012a), and some examples of key findings are given below.

In one of Godfrey Thomson's lectures he stated that: 'For some things which appear later, having been absent in childhood, are nevertheless due to heredity-for example a ginger moustache!' (Thomson 1952a; Figure 9). When we studied the Lothian Birth Cohort of 1921 and divided them into those who are positive and negative for possession of the e4 allele of the gene for apolipoprotein $\mathrm{E}$ ( $A P O E$ : which is risk factor for dementia), we found that it was associated with an intelligence test score in an interesting way (Deary et al. 2002). That is, those who were e4 positive had the same level of intelligence in childhood as those who were e4 negative, but they had significantly lower intelligence in old age, on the same test (Moray House Test No. 12). Here we discovered an example of a genetic contribution to intelligence which had an effect only at one point in the life course; i.e. in old age. This might be associated with apolipoprotein E's being involved in neuronal repair. We have subsequently found the e4 allele of $A P O E$ to be replicated as a risk factor for accelerated cognitive ageing in a meta-analysis of genome-wide association studies, and in replication samples (Davies et al. in press).

The finding that people who have one or more e4 alleles of the $A P O E$ gene tend to have greater negative change in cognition from childhood to old age stands out because there have been few, if any, other single gene variants about which this can be said (Deary et al. 2012a). However, a different approach can be taken to examining genetic factors, and has been used in our studies. The example of $A P O E$ is called a candidate gene study; that is, one identifies variation in one of the 20,000 or so human genes and then asks the question of whether this is associated with age-related cogni- 


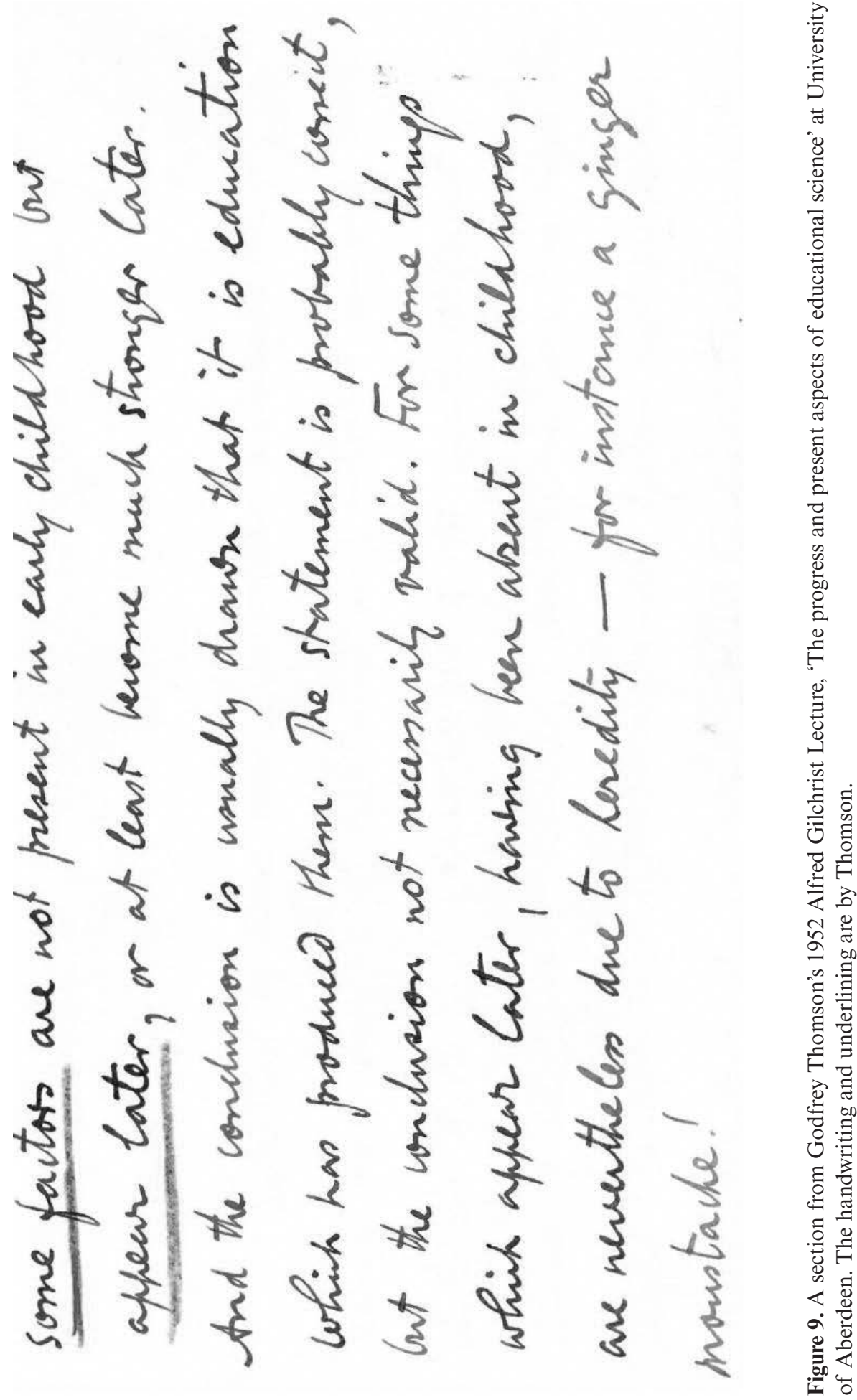


tive change. A different approach is to ask whether genetic differences in general are associated with cognitive function in old age and cognitive change across the life course. This approach involved testing individuals for their genetic status at about half a million sites on their genome.

The follow-up studies of the Scottish Mental Surveys (Aberdeen and Lothian) were involved in the first study of the heritability of intelligence in old age which is based upon DNA analysis rather than on twins or adoptees (Davies et al. 2011). This was heralded by some of Thomson's comments (from about 1929):

Where only one Mendelian factor is concerned, as in the case of the dwarf and the tall peas, there will be discontinuity. But where several are needed, or perhaps a hundred, then we obtain the same fine grading that is possible when we have small units to weigh up or measure with.

We used genome-wide association analysis with cognitive test data in five samples in Scotland and England, all of whom had been tested on over 600,000 single nucleotide polymorphisms. To these samples we applied a new statistical method called GCTA. In simple terms, this novel method allows one to calculate the genetic similarities between unrelated individuals, based on the genetic variants they have at hundreds of thousands of sites on the genome. This genetic similarity - based on testing of their DNA - is then correlated with their phenotypic similarity, which in this case was in cognitive abilities. We found two things: that the heritability of cognitive abilities in old age, based on DNA analysis of common polymorphisms, was between $40 \%$ and $50 \%$; and that the heritability was based on a very large number of small genetic effects. This means that differences in people's cognitive skills in old age is in substantial part due to genetic differences, and that these genetic differences arise from the effects of a very large number of genes and that each of the individual genetic effects is small. Further analysis of genome-wide single nucleotide polymorphism scanning on only the Scottish cohorts estimated that the genetic contribution to changes in cognitive function between childhood and old age was about 25\% (Deary et al. 2012b). This leaves the majority-75\% - due to the environment. Again, it is clear that it is only the Scottish Mental Surveys that would allow us to test these important contributions to change in cognitive function across the entire life course.

To date, then, there are two key genetic results from our work: that people's differences in the $A P O E$ gene contribute a small amount to how well their cognitive functions will age from childhood to old age, and that a large number of genetic factors each with even smaller effects probably account for about a quarter of people's changes in cognitive skill across the life course. The next stages in the genetic research include our trying to track down the sites in the genome that contribute the genetic effects, and our studying epigenetic contributions, i.e. how the environment activates 
and deactivates certain sites in the genome and how these changes influence cognitive ageing.

Moving on from genetic influences, our research has asked whether a healthy body contributes to a healthy mind in old age. With regard to cognitive ageing we were acting in accord with one of Thomson's (around 1929) ideas

These numerous factors concerned in deciding the intelligence of an individual need not all be factors influencing the nervous system, the brain and the spinal cord, directly. You know the old pun in answer to the question, 'Is life worth living?' 'That depends on the liver'. Whether a man's brain is worth anything may very well depend not only on the brain itself, but upon the liver, and indeed upon all the endocrine glands as well...

This makes sense, of course. The brain is one organ of the body. It shares, for example, the vascular system that supplies the rest of the body. If there are general effects of health that affect the body generally, then they might well influence the brain too. We found, using the Lothian Birth Cohort 1921 sample, that Thomson was, to some extent, correct (Deary et al. 2006). In this study we first found that, after taking childhood Moray House Test intelligence scores into account, sex, occupational social class, and the apolipoprotein gene's e4 status contributed to people's cognitive ability in old age. That is, men and those with a more professional job did slightly better on cognitive tests in old age than would be predicted from their cognitive ability in childhood. In addition to those factors, people's physical fitness was associated with their cognitive ability at almost age 80 . Those who had better lung function, better hand grip strength, and faster walking speed had better cognitive ability at age 79 .

We have tested and published on a number of potential lifestyle contributors to cognitive function in old age (controlling for cognitive function in youth). In some of these we have shown the special ability of the follow-up studies of the Scottish Mental Surveys to detect the important and problematic phenomena of confounding or reverse causation. For example, we found that people in older age who drink more coffee (Corley et al. 2010b), and more alcohol (Corley et al. 2011), and who have a lower body mass index (Corley et al. 2010a), tend to have higher scores on cognitive tests. However, in each of these cross-sectional associations, we found that they were severely attenuated and often reduced to non-significance after accounting for childhood intelligence. Other studies-lacking these unusual childhood cognitive datamight have concluded that such factors were protective to cognitive ageing. Instead, though, the Lothian Birth Cohort 1936 study indicated that these were lifestyle factors in old age that were associated with childhood intelligence, perhaps via mediators such as education, health literacy and social class. Also prey to this confounding by 
childhood intelligence was the association between intellectual engagement and cognitive functions in old age: the Lothian Birth Cohort 1936 data indicated that brighter children tend to grow into older people who take part in more intellectual engagement-type activities, and not that intellectual engagement boosts cognitive ability in older age (Gow et al. 2012a).

Other aspects of lifestyle did appear to contribute to cognitive ability in old age after adjusting for cognitive ability in childhood; that is, they did appear to contribute to healthy cognitive ageing. In the Lothian Birth Cohort 1936 we found that not smoking was one such factor, with the additional twist that it was the children with lower ability at age 11 who were also more likely to take up smoking in the first place (Corley et al. 2012). Another cognitive protective factor was physical activity, with those reporting taking more regular and strenuous exercise also having better cognitive ageing (Gow et al. 2012a). This was given a firmer foundation when we also showed, in the same individuals, that the same physical activity reports in old age were associated with better brain ageing (Gow et al. 2012b). Those taking part in more regular and strenuous physical activity had, for example, less brain atrophy and higher brain white matter integrity.

Within ageing research generally, and including cognitive ageing research, there is a search for biomarkers of ageing. That is, we seek measurable aspects of the body's structure or function, or chemicals that can be measured in the blood or other fluids such as urine and saliva, that might be associated with ageing. In the follow-up studies of the Scottish Mental Surveys we have examined a number of these biomarkers (Deary et al. 2012a). The idea behind biomarkers of ageing research is that there might be some biological index that will indicate how well or badly the body and/or brain have aged that is a better predictor than chronological age. Indeed, the Lothian Birth Cohort studies are especially well suited to such research because they are, within any one of the two cohorts, very similar in chronological age. One such set of ageingrelevant biomarkers are the chemicals associated with inflammation; those people with higher levels of these chemicals are thought to have less advantageous ageing. We tested whether inflammation - in the form of a blood-borne index - contributed to cognitive ageing. The Lothian Birth Cohort 1936 were measured on an inflammatory marker called C-reactive protein (CRP) from their blood samples (Luciano et al. 2009). CRP is only one measure of the body's level of inflammation. In prior studies it had been found that having more CRP was slightly associated with lower cognitive function. We replicated this association in the Lothian Birth Cohort of 1936. However, when we adjusted for the level of cognitive ability at age 11, the association was markedly attenuated. Our conclusion was, therefore, that we had again found evidence for confounding and possibly for reverse causation. That is, a possible account of our results was that higher cognition at age 11 was associated with less inflammation and 
higher cognition at old age, but that CRP did not have a causal influence on cognition contemporaneously in old age. Other biomarker factors that we are examining, or planning to examine, to study cognitive ageing (and are using to investigate confounding and possible reverse causation) include: cytomegalovirus infection (Gow et al. 2013), teleomere length, oxidative stress, blood brain barrier integrity, retinal vessel topography, carotoid artery stenosis, and atherosclerotic indices.

One set of biomarkers we have concentrated on especially with respect to people's differences in cognitive ageing are those derived from brain structure. Here, again, we find a herald from Thomson (1930c):

For me, intelligence is not a kind of spiritual energy, of which one man has a quart while another has a pint. That is a useful way of speaking with some people, as the 'juice' theory of electricity is useful in talking to the plumber, but it is no more. For me, neither the mind nor even the brain is analysable in any so simple a matter into parts. The mind is one complexity, and in the main it is complexity which distinguishes the more able mind from the less able.

Following up this idea, we examined, in the Lothian Birth Cohort of 1936, the integrity of the billions of white matter connections which comprise the complexity with which the brain's regions are connected with each other (Penke et al. 2012). We used magnetic resonance brain scanning to obtain three different measures of the brain's white matter integrity. We found that, together, these assessments of brain white matter integrity contributed about $10 \%$ of the variance to general cognitive function in old age. Moreover, the association between white matter integrity and general cognitive ability was entirely mediated by processing speed. This means that better brain connections are associated with faster speed of thinking, which in turn is associated with better general cognitive ability in older age. This finding requires that more research be conducted on the causes and mechanisms of healthy brain white matter ageing.

To summarise this section, the follow-up studies of the Scottish Mental Surveys are making a contribution to understanding the important topic of why people's thinking skills and brains age differently. They bring the advantages of having a baseline cognitive ability test in youth, of being groups of individuals of about the same chronological age, and of being thoroughly examined for a wide range of possible determinants. It should also be mentioned that the determinants noted aboveat least, those that are not found to be associated with confounding-tend to make small contributions to the variation in cognitive function in old age. The picture that is emerging is that cognitive ability in old age is substantially determined by life-long, stable cognitive trait level and also by a variety of small effects that range from genetics and social background to lifestyle and health factors. 


\section{Further research on cognitive epidemiology}

The research using the Scottish Mental Surveys' data that is focused on cognitive ageing uses cognitive test scores in old age as the outcomes, and the data from the 1932 and 1947 surveys as important covariates. On the other hand, what characterises cognitive epidemiology is that the scores from the 1932 and 1947 Scottish Mental Surveys are used as the predictors of important life outcomes such as, as we saw above, survival. Much of the international research that has followed up on our original demonstration that childhood intelligence was associated with survival to old age was summarised in Deary et al. (2010a). This has tested whether childhood intelligence is associated with different causes of death, whether childhood intelligence is associated with the risk of certain illnesses, and has looked for possible mediators and confounders of the association. Here, I give some examples of follow-up research that used data from the Scottish Mental Surveys.

In our cognitive epidemiology work we examined, not just mortality, but some specific illnesses. These illnesses included mental and physical states (see Deary et al. 2010a). One of the important findings had to do with childhood cognitive ability and dementia (McGurn et al. 2008). The widely used term called 'cognitive reserve' refers to the idea that people with higher mental ability or more education have built up some cognitive reserve 'in the bank'. Thus, when they are hit with the pathology of dementia (or similar illnesses), they are somewhat protected and retain a higher level of cognition when compared with those with lower cognitive reserve and the same amount of pathology. We found that this was not so straightforward. The study of those born in 1921 found that those with higher childhood cognitive ability seemed to be protected to some extent against vascular dementia, but were at the same risk of late-onset Alzheimer's disease. We speculated that the greater risk of vascular rather than Alzheimer's-type dementia in those with lower intelligence might have been due to the association between childhood intelligence and cardiovascular function which had been found elsewhere (Deary et al. 2010a); that is, those people with more cardiovascular pathology are at greater risk of vascular dementia.

In another study we added to the predictors of all-cause mortality by testing whether some childhood personality traits are associated with all-cause mortality in addition to intelligence. One of the most studied subsamples of the Scottish Mental Survey 1947 was the so-called 6-Day Sample (Deary et al. 2009a). This involved the people born on the first day of the even-numbered months of 1936. There were 1,208 of these individuals, and almost all were followed individually for 16 years until they were aged 27. Their younger siblings were also given IQ tests as they turned age 11 . This was an extraordinary follow-up study over a number of years largely using unpaid researchers. In one of our follow-up studies we took the 6-Day Sample's intel- 
ligence test data and added to it some character ratings which had been made by teachers at about age 14 (Deary et al. 2008b). We put together some of the character items' ratings to form a personality scale of 'dependability' which involved ratings of each child's 'perseverance', 'conscientiousness', and 'stability of moods'. We found that both intelligence from age 11 and teacher-rated personality from age 14 made significant and independent contributions to survival over a 55 -year period. We used an epidemiological statistical technique called Cox's proportional hazards regression to analyse this, and the analyses were presented as hazard ratios. Here, though, I illustrate the findings by simply dividing the sample at the mean into low and high intelligence and dependability in childhood, and looking at the percentage who had died 55 years later. Someone high in both intelligence and dependability in youth had a $9.6 \%$ chance of dying between youth and 55 years of follow up. On the other hand, someone low in both of these psychological characteristics had a $24.4 \%$ chance of dying between age 11 and their mid-60s. Therefore in addition to intelligence there appear to be personality aspects that are associated with survival.

It is well known that intelligence in childhood is associated with people's education and social class: the three variables are correlated. They are also all related to health outcomes, including survival (Deary et al. 2010a). Therefore, using the Scottish Mental Surveys' data to study how childhood intelligence related to later social class was an important part of the work on cognitive epidemiology, as well as important in understanding how intelligence was related to social mobility. Social mobility was of great interest to Thomson, not just because of his personal background, but also because of his lifetime's work. Over a number of articles we have clearly found that there is both some meritocracy and some social inertia in the Scottish population. That is, intelligence, education, and a person's social background all contributed to their social position in mid-life and old age. We found some indication that intelligence becomes a stronger predictor of social position later in life (Deary et al. 2005). This is sometimes called the gravitational hypothesis, whereby people of high ability eventually rise to their level of attainment after being held back originally by a poorer social background. Also, we have found effects across three generations of social class and education such that grandfather status can affect grandchildren status on these factors (Johnson et al. 2010). There is no simple picture of there either being strong social determination or meritocracy owing to intelligence. One limitation of the Scottish Mental Surveys is that there is little opportunity to look at motivation, which is clearly important for social mobility in addition to intelligence.

Cognitive epidemiology is part of life course research: the recognition that influences on health in older age occur throughout life, and involve genetic, developmental and social factors. The follow-up studies of the Scottish Mental Surveys have helped to put cognitive ability differences on the map for life course research. It is not yet 
understood why cognitive ability from as far back as age 11 is associated with all cause mortality, some specific causes of mortality and with sundry health and illness outcomes, but omitting this variable is to leave out something with a potentially tractable set of causes and mechanisms.

\section{Examples of other uses of the Scottish Mental Surveys' data}

Beyond cognitive ageing and cognitive epidemiology research, the unique aspects of the Scottish Mental Surveys have allowed us to ask other questions. The factors that characterise the usefulness of the Surveys' data are their comprehensiveness and the fact that they constitute, from childhood on, a sample of older people. I illustrate this with some examples.

The Scottish Mental Survey of 1932 allowed us to make an unusually comprehensive study of childhood sex differences in intelligence (Deary et al. 2003). As far as we know, this is the only full-population study, and so it allows us to test whether there are any differences in general intelligence between boys and girls without fear of selection bias in the sample. What we found was that there was no mean difference - even with about 40,000 subjects in each group - between boys and girls on mean intelligence. However, there was a difference in the spread of intelligence in the two sexes. Boys had a larger standard deviation. The practical consequence of this is that there tend to be more girls in the population compared to the boys who have about mean levels of intelligence. There is a greater proportion of boys at the lower levels of intelligence and also at the upper end. This was replicated in the Scottish Mental Survey of 1947 (Johnson et al. 2008), and has been replicated in large-scale studies in the UK (Strand et al. 2006) and the USA (Lohman et al. 2009): it seems to be a robust finding that boys are more extreme in intelligence, with greater representation at the lowest and highest levels of intelligence.

Another unusual and valuable use of the Scottish Mental Surveys was in testing whether it was valid to use assessments of vocabulary or, more specifically, pronunciation of printed words, to try and obtain an estimate of people's so-called premorbid or prior intelligence level. This is important for clinical states such as dementia, where one is trying to assess how bright people used to be before the onset of cognitive decline. There are widely used tests such as the National Adult Reading Test (NART), which involve the person spending a few minutes trying to pronounce 50 irregular English words. Because they are irregular, in grapheme-phoneme relations and/or in stress, it is thought that people will only pronounce the words correctly if they have seen them before. This cognitive test requires little active thinking. We were able to find the people with and without dementia who had taken the Scottish Mental Survey intelligence test (McGurn et al. 2004). What we found was that there was a strong correlation ( $r$ greater than 0.6 ) between NART tests taken at about age 80 and the Scottish Mental Survey intelligence test taken in 1932, in both the people with dementia and 
those without. Therefore, we concluded that assessment with the NART is a valid way of estimating people's prior intelligence, both in those with and without early dementia.

Not everything with the Scottish Mental Survey data shows that higher intelligence in childhood is associated with better outcomes in old age. One of these findings was an entirely null study which we published in the British Medical Journal (Gow et al. 2005). We found that the association between Moray House test scores at age 11 and self-rated satisfaction with life (using Diener's satisfaction with life scale) was zero. That is, there was no association between childhood intelligence and how satisfied people were with their life at age 80 .

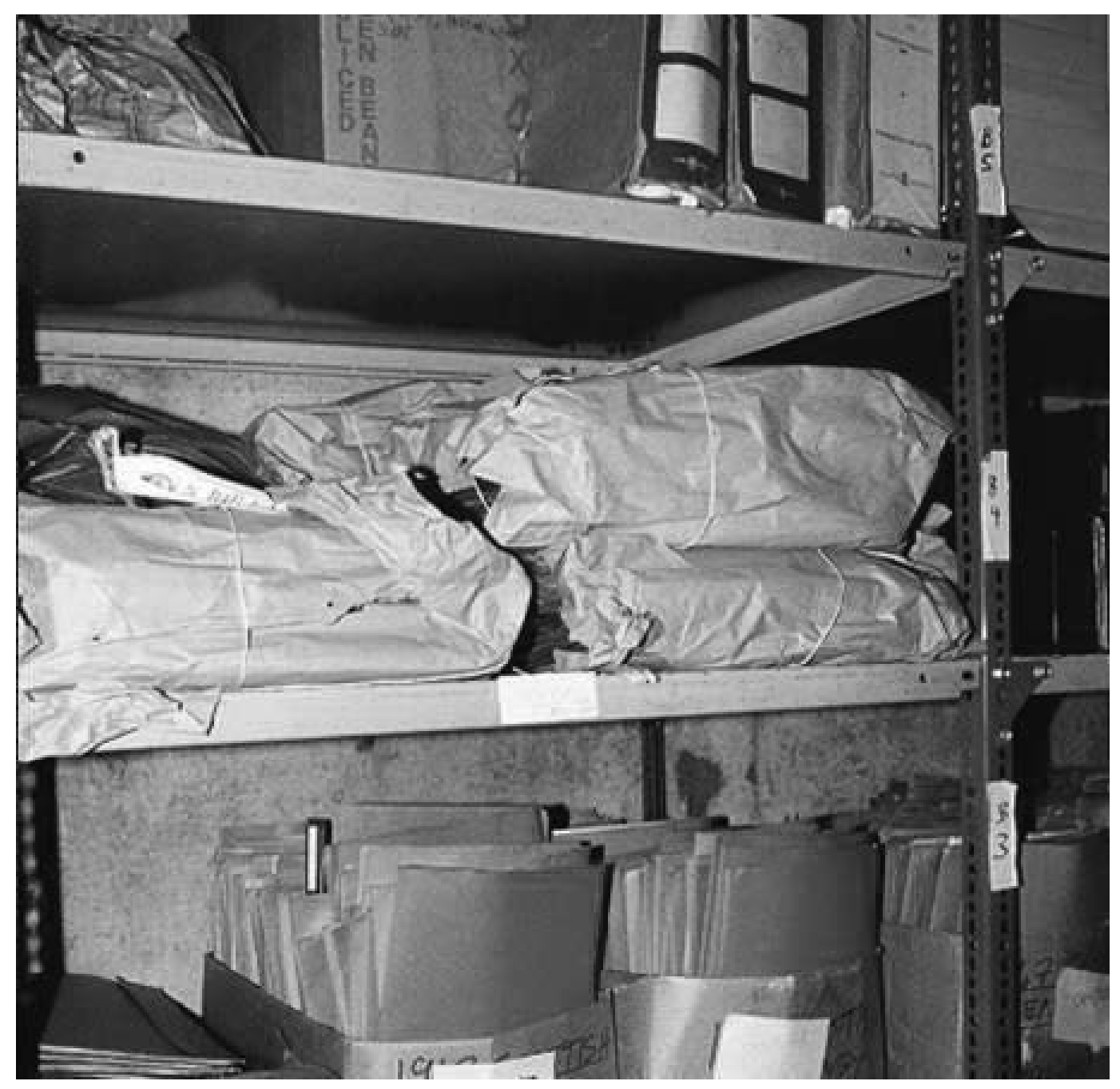

Figure 10. The folders that contain data from the individuals in the 6-Day Sample of the Scottish Mental Survey 1947. The photograph was taken in 1997 in the basement of Charteris Land at Moray House College, University of Edinburgh. Photograph copyright Ian Deary. 


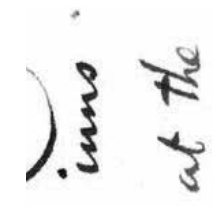

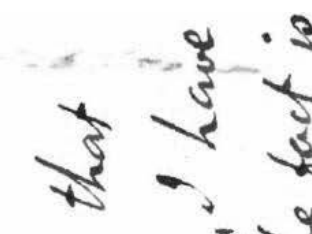

赵

तै

है तै

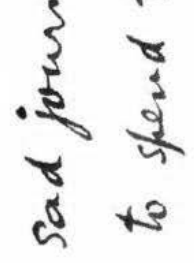

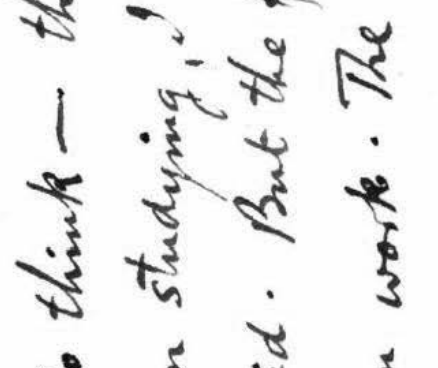

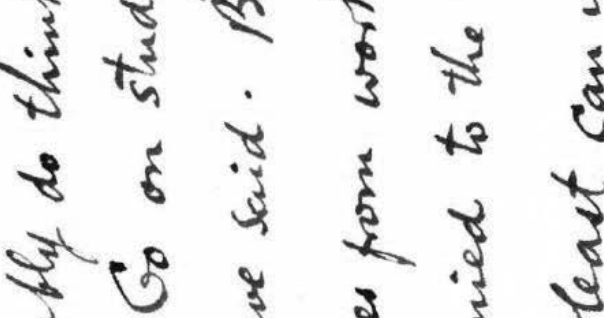

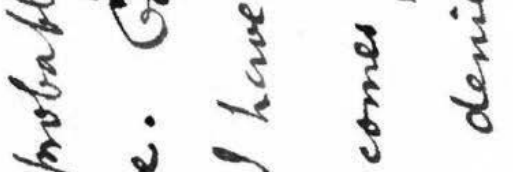

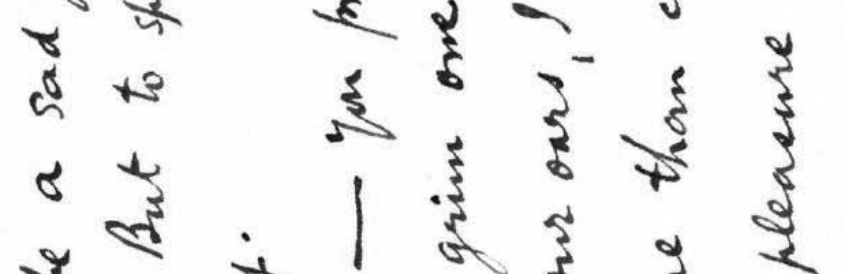

र्रले के दे के है

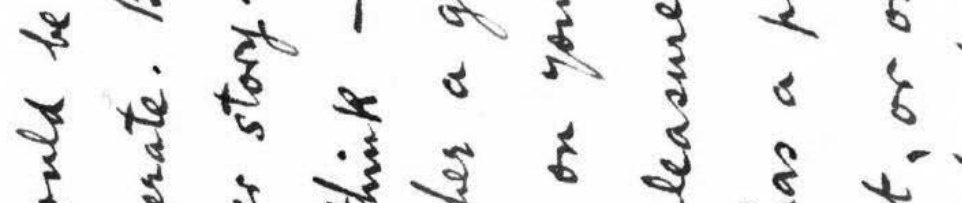

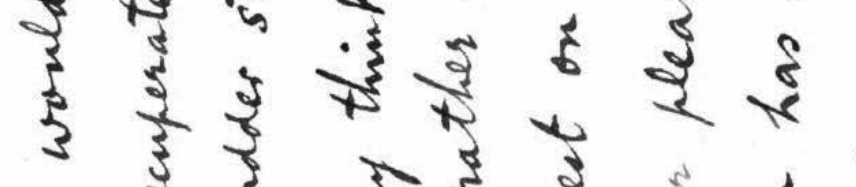

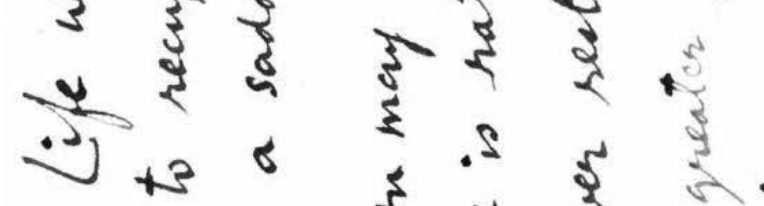

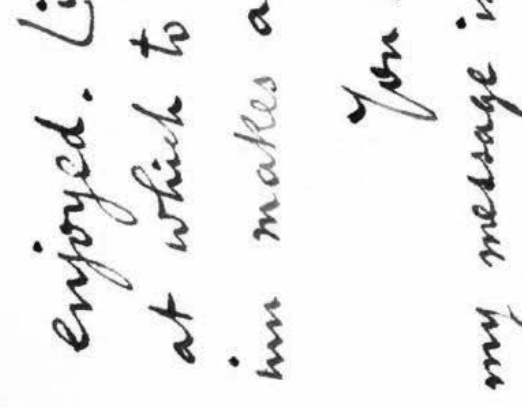

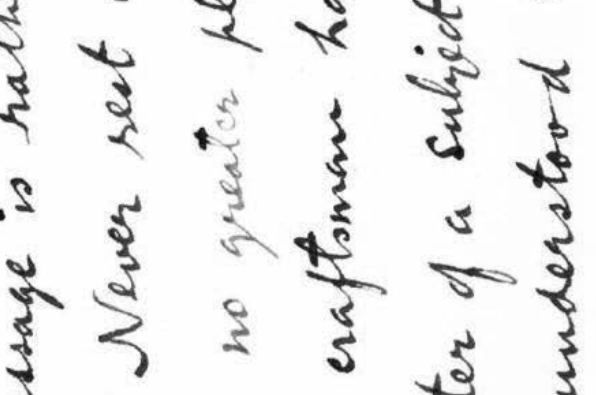

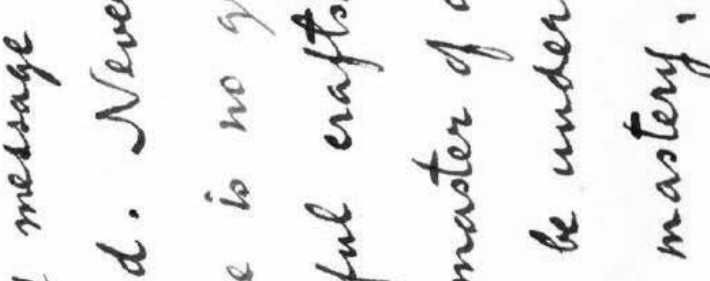




\section{CONCLUSION}

In trying to capture the joint audiences from the British Academy and from the British Psychological Society, I have illustrated in this article that we are at the same time still trying to understand Godfrey Thomson's life and work, and his contributions to the Scottish Mental Surveys, while also following up the Scottish Mental Survey data. Our work for the future will be to follow up the Lothian Birth Cohorts of 1921 and 1936 into their even older age, and these individuals are still highly committed to these studies (Deary et al. 2012a). In addition, we have set out on a new cohort study, whereby we are now trying to follow up the 6-Day Sample Scottish Mental Survey 1947. This largely stopped in 1969 when funding ran out. It seemed a pity that such an intensive study of a group of individuals between age 11 and 27, that was so clearly representative of the whole of Scotland, should be left unfinished (Figure 10). We shall therefore be studying the life and health of the 6-Day Sample and relating the results back to all the data which were collected between 11 and 27.

In conclusion, I again quote Godfrey Thomson (1954; Figure 11) from his last lecture, a year before he died:

So do not rest on your oars. It is never time to rest on your oars, but least of all in these years just ahead of you [he was talking to newly qualified teachers]. There are of course

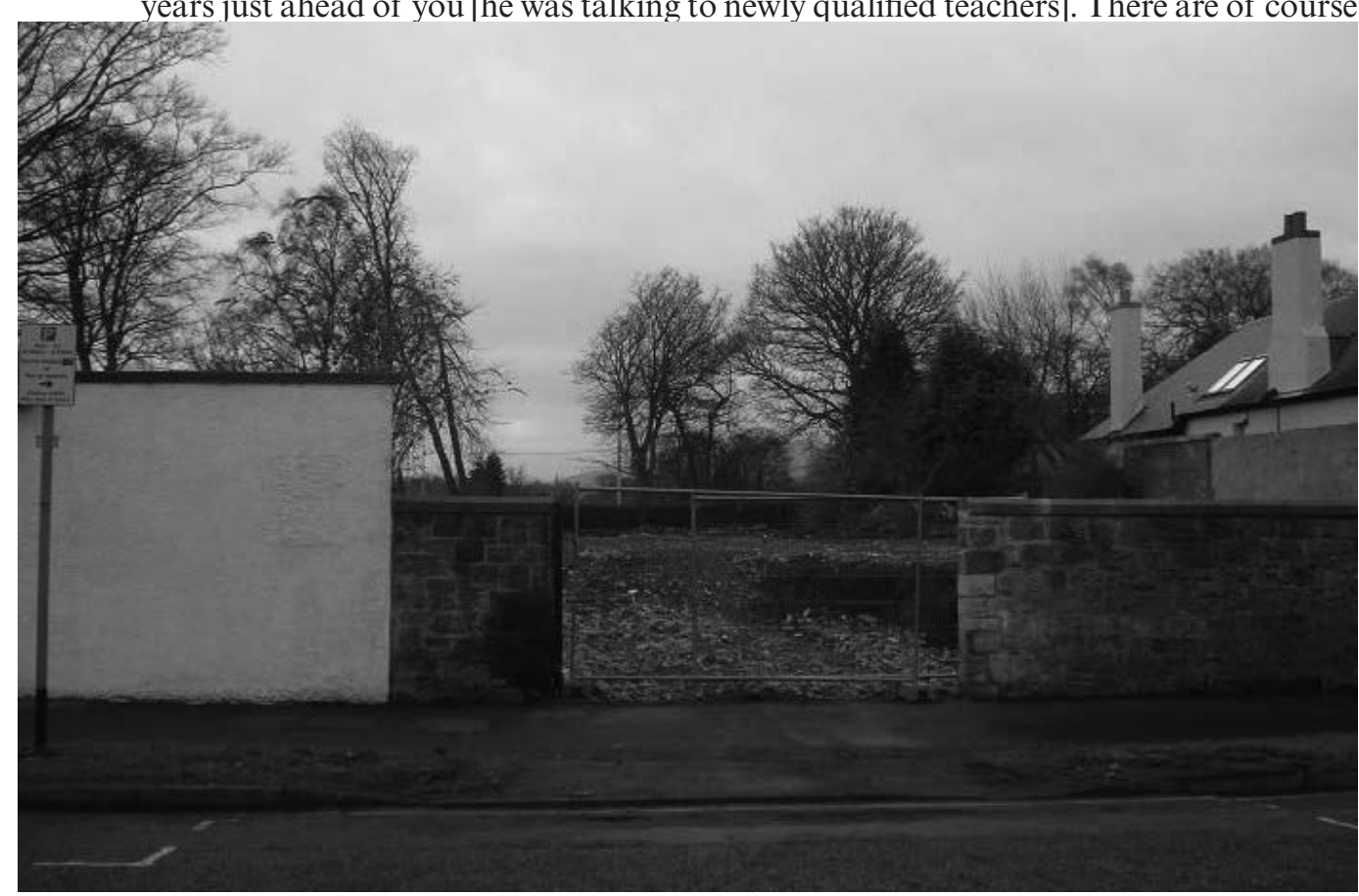

Figure 12. The site where Godfrey Thomson's house had been, taken about two years after the retrieval of the Hector Thomson Collection. Photograph copyright Ian Deary. 
vacations legitimately to be enjoyed. Life would be a sad journey without its inns at which to recuperate. But to spend the whole of life at the inn makes a sadder story.

You may think - you probably do think - that my message is rather a grim one. Go on studying, I have said. Never rest on your oars, I have said. But the fact is there is no greater pleasure than comes from work. The skilful craftsman has a pleasure denied to the labourer. The master of a subject, or one who at least can understand and be understood by the master, has a like pleasure. And with mastery, won in most cases before thirty, comes leisure which can be truly enjoyed, not leisure stolen from duty.

At the beginning of this article, I noted that it was about two buildings. The opportunity afforded by the visit to 5 Ravelston Dykes that resulted in so many previously unknown Thomson sources proved to be timely. A short time after the visit, the house was razed to the ground in preparation for a new one (Figure 12).

\section{Acknowledgements}

The work was undertaken in The University of Edinburgh Centre for Cognitive Ageing and Cognitive Epidemiology, part of the cross council Life Long Health and Wellbeing Initiative (G0700704/84698). Funding from the Biotechnology and Biological Sciences Research Council (BBSRC), Engineering and Physical Sciences Research Council (EPSRC), Economic and Social Research Council (ESRC) and Medical Research Council (MRC) is gratefully acknowledged. I thank: the Aberdeen and Lothian Birth Cohort teams; the team working on historical aspects of Godfrey Thomson's work (Martin Lawn, David Bartholomew, Caroline Brett, and Alison Pattie); Scottish Council for Research in Education; and Annabella Senior for donating the Hector Thomson collection.

\section{REFERENCES}

Anderson, S. (2007), Interview with Ian J. Deary in Psychology Department at the University of Edinburgh. Interview and transcript in Special Collections, University of Edinburgh Main Library.

Bartholomew, D., Deary, I.J. \& Lawn, M. (2009a), 'A new lease of life for Thomson's bonds model of intelligence', Psychological Review, 116: 567-79. http://dx.doi.org/10.1037/a0016262 PMid:19618987

Bartholomew, D., Deary, I.J. \& Lawn, M. (2009b), 'The origin of factor scores: Spearman, Thomson and Bartlett', British Journal of Mathematical and Statistical Psychology, 62: 569-82. http://dx.doi.org/10.1348/000711008X365676 PMid:19321036

Bartholomew, D., Deary, I.J. \& Lawn, M. (2009c), 'Sir Godfrey Thomson: a statistical pioneer', Journal of the Royal Statistical Society Series A, 172: 467-82. http://dx.doi.org/10.1111/j.1467-985X.2008.00567.x

Calvin, C.M., Deary, I.J., Fenton, C., Roberts, B., Der, G., Leckenby, N. \& Batty, G.D. (2011), 'Intelligence in youth and all cause mortality: systematic review and meta-analysis', International Journal of 
Epidemiology, 40: 626-44. http://dx.doi.org/10.1093/ije/dyq190

PMid:21037248 PMCid:PMC3147066

Corley, J., Gow, A.J., Starr, J.M. \& Deary, I.J. (2010a), 'Is body mass index in old age related to cognitive abilities? The Lothian Birth Cohort 1936 studies', Psychology and Aging, 25: 867-75. http://dx.doi.org/10.1037/a0020301 PMid:21186916

Corley, J., Gow, A.J., Starr, J.M. \& Deary, I.J. (2012), 'Smoking, childhood IQ, and cognitive function in old age', Journal of Psychosomatic Research, 73: 132-8.

http://dx.doi.org/10.1016/j.jpsychores.2012.03.006 PMid:22789417

Corley, J., Jia, X., Kyle, J.A.M., Gow, A.J., Brett, C.E., Starr, J.M., McNeill, G. \& Deary, I.J. (2010b), 'Caffeine consumption and cognitive function at age 70: the Lothian Birth Cohort 1936 study', Psychosomatic Medicine, 72: 206-14. http://dx.doi.org/10.1097/PSY.0b013e3181c92a9c PMid:19995882

Corley, J., Jia, X., Brett, C.E., Gow, A.J., Starr, J.M., Kyle, J.A.M., McNeill, G. \& Deary, I.J. (2011), 'Alcohol intake and cognitive abilities in old age: the Lothian Birth Cohort 1936 study', Neuropsychology, 25: 166-75. http://dx.doi.org/10.1037/a0021571 PMid:21381824

Davies, G., Tenesa, A., Payton, A., Yang, J., Harris, S.E., Liewald, D.C. et al. (2011), 'Genome-wide association studies establish that human intelligence is highly heritable and polygenic', Molecular Psychiatry, 16: 996-1005. http://dx.doi.org/10.1038/mp.2011.85

PMid:21826061 PMCid:PMC3182557

Davies, G., Harris, S.E., Reynolds, C.A., Payton, A., Knight, H.M., Liewald, D.C. et al. (in press), 'A genome-wide association study implicates the APOE locus in non-pathological cognitive ageing', Molecular Psychiatry. http://dx.doi.org/10.1038/mp.2012.159

Deary, I.J., Lawn, M. \& Bartholomew D.J. (2008a), 'A conversation between Charles Spearman, Godfrey Thomson, and Edward L. Thorndike: the International Examinations Inquiry 1931-1938', History of Psychology, 11: 122-42. http://dx.doi.org/10.1037/1093-4510.11.2.122

Deary, I.J., Whalley, L.J. \& Starr, J.M. (2009a), A Lifetime of Intelligence: Follow-up Studies of the Scottish Mental Surveys of 1932 and 1947 (Washington, DC: American Psychological Association). http://dx.doi.org/10.1037/11857-000

Deary, I.J., Weiss, A. \& Batty, G.D. (2010a), 'Intelligence and personality as predictors of illness and death: how researchers in differential psychology and chronic disease epidemiology are collaborating to understand and address health inequalities', Psychological Science in the Public Interest, 11: 53-79. http://dx.doi.org/10.1177/1529100610387081

Deary, I.J., Whalley, L.J., Batty, G.D. \& Starr, J.M. (2006), 'Physical fitness and lifetime cognitive change', Neurology, 67: 1195-200. http://dx.doi.org/10.1212/01.wnl.0000238520.06958.6a PMid:17030752

Deary, I.J., Batty, G.D., Pattie, A. \& Gale, C.R. (2008b), 'More intelligent, more dependable children live longer: a 55-year longitudinal study of a representative sample of the Scottish nation', Psychological Science, 19: 874-80. http://dx.doi.org/10.1111/j.1467-9280.2008.02171.x PMid:18947352

Deary, I.J., Lawn, M., Brett, C.E. \& Bartholomew D.J. (2009b), “Intelligence and civilisation”: a Ludwig Mond lecture delivered at the University of Manchester on 23rd October 1936 by Godfrey H. Thomson: a reprinting with background and commentary', Intelligence, 37: 48-61. http://dx.doi.org/10.1016/j.intell.2008.07.005

Deary, I.J., Gow, A.J., Pattie, A. \& Starr, J.M. (2012a), 'Cohort profile: the Lothian Birth Cohorts of 1921 and 1936', International Journal of Epidemiology, 41: 1576-84. http://dx.doi.org/10.1093/ije/dyr197 PMid:22253310

Deary, I.J., Whalley, L.J., Lemmon, H., Crawford J.R. \& Starr, J.M. (2000), 'The stability of individual differences in mental ability from childhood to old age: follow-up of the 1932 Scottish Mental Survey', Intelligence, 28: 49-55. http://dx.doi.org/10.1016/S0160-2896(99)00031-8 
Deary, I.J., Thorpe, G., Wilson, V., Starr, J.M. \& Whalley, L.J. (2003), 'Population sex differences in IQ at age 11: The Scottish Mental Survey 1932', Intelligence, 31: 533-42.

http://dx.doi.org/10.1016/S0160-2896(03)00053-9

Deary, I.J., Whiteman, M.C., Starr, J.M., Whalley, L.J. \& Fox, H.C. (2004), 'The impact of childhood intelligence on later life: following up the Scottish Mental Surveys of 1932 and 1947', Journal of Personality and Social Psychology, 86: 130-47. http://dx.doi.org/10.1037/0022-3514.86.1.130 PMid:14717632

Deary, I.J., Lawn, M., Brett, C.E., Pattie, A. \& Bartholomew D.J. (2010b), 'Archival sources for Sir Godfrey Hilton Thomson', History of Psychology, 13: 95-103. http://dx.doi.org/10.1037/a0018529

Deary, I.J., Yang, J., Davies, G., Harris, S.E., Tenesa, A., Liewald, D.C. et al. (2012b), 'Genetic contributions to stability and change in intelligence from childhood to old age', Nature, 482: 212-15. PMid:22258510

Deary, I.J., Whiteman, M.C., Pattie, A., Starr, J.M., Hayward, C., Wright, A.F., Carothers, A. \& Whalley, L.J. (2002), 'Cognitive change and the APOE e4 allele', Nature, 418: 932. http://dx.doi.org/10.1038/418932a PMid:12198535

Deary, I.J., Taylor, M.D., Hart, C.L., Wilson, V., Davey Smith, G., Blane, D. \& Starr, J.M. (2005), 'Intergenerational social mobility and mid-life status attainment: influences of childhood intelligence, childhood social factors, and education', Intelligence, 33, 455-72. http://dx.doi.org/10.1016/j.intell.2005.06.003

Deary, I.J., Gow, A.J., Taylor, M.D., Corley, J., Brett, C., Wilson, V., Campbell, H., Whalley, L.J., Porteous, D.J. \& Starr, J.M. (2007), 'The Lothian Birth Cohort 1936: a study to examine influences on cognitive ageing from age 11 to age 70 and beyond', BMC Geriatrics, 7: 28. http://dx.doi.org/10.1186/1471-2318-7-28 PMid:18053258 PMCid:PMC2222601

Duff, J.F. \& Thomson, G.H. (1923), 'The social and geographical distribution of intelligence in Northumberland', British Journal of Psychology, 14: 193-8.

Gow, A.J., Corley, J., Starr, J.M. \& Deary, I.J. (2012a), 'Reverse causation in activity-cognitive ability associations: the Lothian Birth Cohort 1936', Psychology and Aging, 27: 250-5. http://dx.doi.org/10.1037/a0024144 PMid:21644808

Gow, A.J., Bastin, M.E., Maniega, S.M., Hernandez, M.V., Morris, Z., Murray, C.M., Royle, N., Starr, J.M., Deary, I.J. \& Wardlaw, J.M. (2012b), 'Neuroprotective lifestyles and the aging brain: activity, atrophy and white matter integrity', Neurology, 79: 1802-8. PMid:23091073. http://dx.doi.org/10.1212/WNL.0b013e3182703fd2

Gow, A.J., Firth, C., Harrison, R., Starr, J.M., Moss, P. \& Deary, I.J. (2013), 'Cytomegalovirus infection and cognitive abilities in old age', Neurobiology of Aging, 34: 1846-52. http://dx.doi.org/10.1016/j.neurobiolaging.2013.01.011 PMid:23434472

Gow, A.J., Whiteman, M.C., Pattie, A., Whalley, L.J., Starr, J.M. \& Deary, I.J. (2005), 'Being smart doesn't guarantee happiness: a longitudinal cohort study of the relationship between satisfaction with life in old age and lifetime intellectual function', British Medical Journal, 331: 141-2. http://dx.doi.org/10.1136/bmj.38531.675660.F7 PMid:16000314 PMCid:PMC558700

Gow, A.J., Johnson, W., Pattie, A., Brett, C.E., Roberts, B., Starr, J.M. \& Deary, I.J. (2011), 'Stability and change in intelligence from age 11 to ages 70, 79 and 87: The Lothian Birth Cohorts of 1921 and 1936', Psychology and Aging, 26: 232-40. http://dx.doi.org/10.1037/a0021072 PMid:20973608

Johnson, W., Brett, C.E. \& Deary, I.J. (2010), 'Intergenerational class mobility in Britain: a comparative look across three generations in the Lothian Birth Cohort 1936', Intelligence, 38: 268-81. http://dx.doi.org/10.1016/j.intell.2009.11.010

Johnson, W., Carothers, A. \& Deary, I.J. (2008), 'Sex differences in variability in general intelligence: a new look at an old question', Perspectives on Psychological Science, 3: 518-31. http://dx.doi.org/10.1111/j.1745-6924.2008.00096.x 
Lawn, M., Deary, I.J., Brett, C.E. \& Bartholomew D.J. (2009), 'Godfrey Thomson and the rise of university pedagogical study: a recorded lecture delivered at the University of Edinburgh in November 1950 by Godfrey H. Thomson: a transcript with commentary', History of Education, 38: 565-85. http://dx.doi.org/10.1080/00467600902916561

Lawn, M., Deary, I.J., Bartholomew D.J. \& Brett, C.E. (2010), 'Embedding the new science of research: the organised culture of Scottish educational research in the mid-twentieth century', Pedagogica Historica, 46: 357-81. http://dx.doi.org/10.1080/00309230903396480

Ledermann, W. (2006), Interview with Ian J. Deary in North London. Interview and transcript in Special Collections, University of Edinburgh Main Library.

Lohman, D.F. \& Lakin, J.M. (2009), 'Consistencies in sex differences on the Cognitive Abilities Test across countries, grades, test forms, and cohorts', British Journal of Educational Psychology, 79: 389-407. http://dx.doi.org/10.1348/000709908X354609 PMid:18822186 
Luciano, M.C., Marioni, R.E., Gow, A.J., Starr, J.M. \& Deary, I.J. (2009), 'Reverse causation in the association between C-reactive protein and fibrinogen levels and cognitive abilities in an ageing sample', Psychosomatic Medicine, 71: 404-9. http://dx.doi.org/10.1097/PSY.0b013e3181a24fb9 PMid:19398500

McGurn, B., Deary, I.J. \& Starr, J.M. (2008), 'Childhood cognitive ability and risk of late-onset Alzheimer and vascular dementia', Neurology, 71: 1051-6. http://dx.doi.org/10.1212/01.wnl.0000319692.20283.10 PMid:18579804

McGurn, B., Starr, J.M., Topfer, J.A., Whiteman, M.C., Lemmon, H.A., Whalley, L.J. \& Deary, I.J. (2004), 'Pronunciation of irregular words is preserved in dementia, validating premorbid IQ estimation', Neurology, 62: 1184-6. http://dx.doi.org/10.1212/01.WNL.0000103169.80910.8B PMid:15079021

Nisbet, J. (2006), Interview with Ian J. Deary and Martin Lawn in Moray House at the University of Edinburgh. Interview and transcript in Special Collections, University of Edinburgh Main Library.

Penke, L. Maniega, S.M., Bastin, M.E., Hernandez, M.C.V., Murray, C., Royle, N.A., Starr, J.M., Wardlae, J.M. \& Deary, I.J. (2012), 'Brain white matter integrity as a neural foundation for general intelligence', Molecular Psychiatry, 17: 1026-30. http://dx.doi.org/10.1038/mp.2012.66 PMid:22614288

Ramsden, E. (2007), 'A differential paradox: the controversy surrounding the Scottish Mental Surveys of intelligence and family size', Journal of the History of the Behavioral Sciences, 43: 109-34. http://dx.doi.org/10.1002/jhbs.20219 PMid:17421031

Scottish Council for Research in Education (1933), The Intelligence of Scottish Children (London: University of London Press).

Scottish Council for Research in Education (1949), The Trend of Scottish Intelligence (London: University of London Press).

Sharp, S. (1997), "Much more at home with 3.999 pupils than 4": the contributions to psychometrics of Sir Godfrey Thomson', British Journal of Mathematical and Statistical Psychology, 50: 163-74. http://dx.doi.org/10.1111/j.2044-8317.1997.tb01138.x

Strand, S., Deary, I.J. \& Smith, P. (2006), 'Sex differences in cognitive ability test scores: A UK national picture', British Journal of Educational Psychology, 76: 463-80. http://dx.doi.org/10.1348/000709905X50906 PMid:16953957

Taylor, E. (2007), Interview with Ian J. Deary in Stromness, Orkney. Interview and transcript in Special Collections, University of Edinburgh Main Library.

Thomson, G.H. (1925), 'The food of the Gods', Address to the School Speech Day, Darlington Grammar School. Original lecture in the Hector Thomson Collection, Special Collections, University of Edinburgh Main Library (accession number GB 237 Coll-1310).

Thomson, G.H. (about 1929), 'The extent and significance of individual differences', probably to students in Moray House College at the University of Edinburgh. Original lecture in the Hector Thomson Collection, Special Collections, University of Edinburgh Main Library (accession number GB 237 Coll-1310).

Thomson, G. H. (1930a), 'Some national problems of today: education. Lecture to Dundee University College'. Original lecture in the Hector Thomson Collection, Special Collections, University of Edinburgh Main Library (accession number GB 237 Coll-1310).

Thomson, G. H. (1930b), 'The function of education in the biological record: a lecture to the rationalist press association (Glasgow District)'. Original lecture in the Hector Thomson Collection, Special Collections, University of Edinburgh Main Library (accession number GB 237 Coll-1310).

Thomson, G. H. (1930c), 'The nature of intelligence: Cambridge'. Original lecture in the Hector Thomson Collection, Special Collections, University of Edinburgh Main Library (accession number GB 237 Coll-1310). 
Thomson, G.H. (1942), 'The means to the end-equal opportunity and hard work: King's College Education Society Newcastle'. Original lecture in the Hector Thomson Collection, Special Collections, University of Edinburgh Main Library (accession number GB 237 Coll-1310).

Thomson, G.H. (1943), 'In praise of examinations: Wigan'. Original lecture in the Hector Thomson Collection, Special Collections, University of Edinburgh Main Library (accession number GB 237 Coll-1310).

Thomson, G.H. (1948), 'Talk for sixth forms: Are we becoming less intelligent. British Broadcasting Corporation; Home Service (Schools)'. Original lecture in the Hector Thomson Collection, Special Collections, University of Edinburgh Main Library (accession number GB 237 Coll-1310).

Thomson, G.H. (1950), 'The discovery of talent: Birmingham Rotary Club'. Original lecture in the Hector Thomson Collection, Special Collections, University of Edinburgh Main Library (accession number GB 237 Coll-1310).

Thomson, G.H. (1952a), 'Alfred Gilchrist Lecture: the progress and present aspects of educational science'. Lecture at Aberdeen University. Original lecture in the Hector Thomson Collection, Special Collections, University of Edinburgh Main Library (accession number GB 237 Coll-1310).

Thomson, G.H. (1952b), ‘Godfrey Thomson', in E.G. Boring, H.S. Langfeld, H. Werner \& R.M. Yerkes (eds), A History of Psychology in Autobiography Vol. IV (Worcester, MA: Clark University Press), 279-94.

Thomson, G.H. (1954), 'Aberdeen Training Centre'. Original lecture in the Hector Thomson Collection, Special Collections, University of Edinburgh Main Library (accession number GB 237 Coll-1310).

Vernon, P.E. (1962), 'The contributions to education of Sir Godfrey Thomson', British Journal of Educational Studies, 10: 123-37. http://dx.doi.org/10.1080/00071005.1962.9973074

Wardlaw, J.M., Bastin, M.E., Valdes Hernandez, M.C., Munoz Maniega, S., Royle, N.A., Morris, Z., Clayden, J.D., Sandeman, E.M., Eadie, E., Murray, C., Starr, J.M. \& Deary, I.J. (2011), 'Brain ageing, cognition in youth and old age, and vascular disease in the Lothian Birth Cohort 1936: rationale, design and methodology of the imaging protocol', International Journal of Stroke, 6: 547-59. http://dx.doi.org/10.1111/j.1747-4949.2011.00683.x PMid:22111801

Whalley, L.J. \& Deary, I.J. (2001), 'Longitudinal cohort study of childhood IQ and survival up to age 76', British Medical Journal, 322: 819-22. http://dx.doi.org/10.1136/bmj.322.7290.819

PMid:11290633 PMCid:PMC30556

The author: Ian J. Deary is Professor of Differential Psychology at the University of Edinburgh, and Director of the Medical Research Council-administered Centre for Cognitive Ageing and Cognitive Epidemiology. He graduated in Psychology and Medicine at the University of Edinburgh, and studied there for his Ph.D. He practised psychiatry in London and Edinburgh before moving to academic psychology. His principal research interest is human mental abilities, especially: the origins of cognitive differences; the effects of ageing and medical conditions on mental skills; and the influence of intelligence on health and wellbeing through the life course. He directs the Lothian Birth Cohorts of 1921 and 1936, and the 6-Day Sample follow-up study of the Scottish Mental Survey 1947. He has published over 600 refereed journal art- 
icles, four authored books and three edited books. He held a Royal Society-Wolfson Research Merit Award (2003-7) for his work on human cognitive ageing. In 2010 he received the Distinguished European Personality Psychologist Award from the European Association for Personality Psychology. Recent publications include 'Intelligence', Annual Review of Psychology (2012); and as joint author 'The neuroscience of human intelligence differences', Nature Reviews Neuroscience (2010), 'Genetic contributions to stability and change in intelligence from childhood to old age', Nature (2012), and 'A lifetime of Intelligence: follow-up studies of the Scottish Mental Surveys of 1932 and 1947'. Washington, DC: American Psychological Association (2009). Contact: I.Deary@ed.ac.uk

This article is licensed under a

Creative Commons Attribution-NonCommercial-NoDerivs 3.0 Unported License.

Journal of the British Academy (ISSN 2052-7217) is published by

The British Academy - the national academy for the humanities and social sciences.

10-11 Carlton House Terrace, London, SW1Y 5AH

www.britac.ac.uk 